\title{
A Systematic Literature Review on the Effects of Risk Management Practices on the Performance of Islamic Banking Institutions
}

\author{
Siti NaJihah Noory, Shahida Shahimi* \& Abdul Ghafar Ismail
}

\begin{abstract}
Risk management practices (RMPS) are important for Islamic banking institutions (IBIS) mainly because they represent the risk exposures that may affect their financial stability. The fact that RMPs is not a new activity in IBIs but still attract significant numbers of studies indicate the relevancy of the subject matter. For instance, weak risk management will hamper IBIs' performance and eventually the stakeholders and industry at large. There are still lack of evidence on the effects of RMPs specifically on the IBIs given the nature and unique characteristics of the risks faced by these institutions. This systematic review article focuses on the effects of the RMPs on the performance of IBIs. Systematic literature review (SLR) is used in this study as it produces quality evidence on RMPs with more significant results on the effects of the IBIs' performance. It defers greatly from the conventional literature review because the development of the systematic review is based on the main research question and utilized advanced search provided in the online journal databases. This study used eight (8) electronic journal databases and applied Preferred Reporting Items for Systematic review and Meta-Analysis (PRISMA). Based on the 39 primary studies related to RMPS and performance of IBIS, a total of 16 themes and 17 sub-themes were identified. The study finds that IBIs with good risk mitigation practices, risk management environment, policies and procedures, and risk monitoring have better financial performance. Hence, IBIS must ensure that RMPs a priority within the institutions to increase the financial performance and improve the overall competitiveness in the Islamic banking industry.
\end{abstract}

Keywords: Financial stability; risk management principles; risk mitigation; risk monitoring

\section{INTRODUCTION}

The financial intermediation theory has been widely discussed by many researchers which among others are Sealey and Lindley (1977); Keynes (1936); Werner(2005); Tobin (1963, 1969); Baltensperger (1980); Diamond and Dybvig (1983); Riordan (1993); Kashyap et al. (2002); Diamond and Rajan (2001); Casu et al. (2006) and Cecchetti (2008). According to Mishkin (1997), financial intermediation is the activity of channeling funds from the surplus units to the deficit units in a specific market using financial intermediaries. In this regard, banks as the main financial intermediaries play an important role in economy. Specifically Fry (1988) stated that banks carry out three major functions: first, channeling savings from households to firms and the public sector for investment in the productive sector; second, they create money and administer the mechanism of payments; and third, they bond lenders and borrowers, savers and investors.

In general, banks and its function are closely related to the lending and investment matter. For example, banks are provider of funds between savers and borrowers, providers a means of exchange, provider of risk-sharing mechanism and provider of funds to the central bank to implement government policy. Due to its importance in the financial system and its influence on the economic growth of a country, banks are highly controlled and regulated in most countries. Apart from that, the uses and sources of funds of the bank are embodied in its statement of financial position. Nevertheless, both funds usually come from households, enterprise, government and financial institutions. Hence, banks act as financial intermediaries because they stand between savers/ depositors/ lenders and borrowers/ investors (see, Figure 1).

More elaborately, banks borrow money from the savers and lend to the borrowers. Savers place their money with banks using financial instruments such as a deposit, and then receive the interest from the payments and withdraw money. Borrowers obtain loans from banks and reimburse the loans with interest. While serving the role as financial intermediaries, banks are vulnerable to various financial and non-financial risks. These risks would affect the banks' performance and eventually the stakeholders. Risk is an uncertain event that can manipulate the achievements of banking institutions' objectives, including strategy, transactional as well as disrupt the bank's profitability (Rhanoui \& Belkhoutout 2019) that leads to the possibility of loss or gain. For example, credit or default risk incur when the deficit units may not be able to pay their debt. Furthermore, the surplus units faced the 'liquidity' problem where may not be able to dispose on their claim on the deficit units. Islamic banks, who act as financial intermediaries, also need to adopt effective risk management to mitigate and control the risks exposure. 


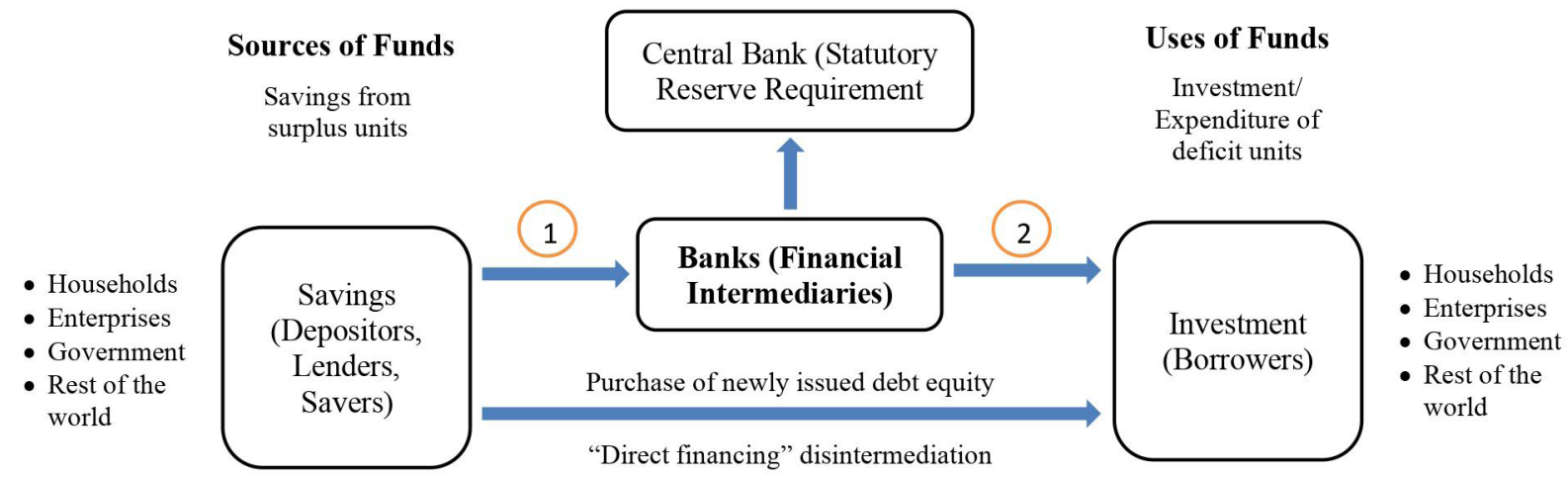

$\begin{array}{ll}\text { (1) Financial Instruments } & \text { Financial Instruments } \\ \text { - Currency } & \text { - Money at call } \\ \text { - Deposits } & \text { - Bills } \\ \text { - Bills } & \text { - Overdraft } \\ \text { - Loans } & \text { - Term loans } \\ \text { - Unit trusts } & \text { - Hire purchase } \\ \text { - Bonds } & \text { - Securities } \\ \text { - etc. } & \text { - etc. }\end{array}$

FIGURE 1. The theory of financial intermediation.

Source: Adapted from Werner (2005) and BNM (1989)

However, risks in Islamic banks are more complex and diverse than conventional banks because of the features of products and services. According to Al-Hares and Salem (2017), the fundamental of Islamic banking are different from conventional banking where the main activities of conventional banks are circulated with loans and interests, whereas Islamic banks' activity are based on profit loss sharing (musyarakah and mudarabah) and mark-up financing (murabahah). Undoubtedly, Islamic banks' products have led to many risks. For instance, liquidity risk, market risk, foreign-exchange risk, credit risk and unique risks (State Bank of Pakistan 2007). Thus, risks exposure can threaten the success and survival of Islamic banking industry which are highly dependent on the ability in managing the risks (Khan \& Ahmed 2001). Furthermore, Al-Tamimi \& Al-Mazrooei (2007) claimed that Islamic banking institutions (IBIs) need to manage risk prudently and effectively.

Risk management is a practice of identifying, measuring, monitoring and controlling the nature of risks faces in every banking institution. It is not onetime process but an ongoing process which directly relies on change in the external and internal environment of Islamic banking that requires continuous attention for risk identification and risk controlling (Hussain \& Al-Ajmi 2012). Meanwhile, Rosman (2009) proposed a research framework on risk management process namely understanding risk and risk management (URM), risk identification (RI), risk monitoring (RM) and risk assessment and analysis (RAA). Iqbal and Mirakhor (2007) indicate that effective risk management practices (RMPs) can help banks to mitigate the risk exposure, as well as to provide good outcomes to the shareholders (AlTamimi \& Al-Mazrooei 2007; Akkizidis \& Khandelwal 2007). Furthermore, prudent risk management is typical to avoid financial problems which can cause widespread of financial crisis (Mohd Ariffin \& Kassim 2011). Apart from that, the rapid growth and sustainability of Islamic banking industry demonstrate its systemic importance to the global banking system. It relies on their capability and skill to handle with the quickly changing landscape of the banking systems and managing the inherent risk of Islamic banking services. Therefore, it is important for risk manager to have thoroughly understanding of risk exposure and risk measurement to perform the tasks entrusted to them effectively (Mokni et al. 2012).

Notwithstanding, weak risk management has been identified as one of the main causes of financial crisis (Sabato 2009; Bank for International Settlements 2009; Holland 2010; KPMG International 2009). The collapse of Lehman Brothers in 2008 reflects the largest bankruptcy in the US history linked to the severity of financial crisis. Also, the subprime mortgage crisis has thought witnesses a number of collapse and near collapse. Nevertheless, the fluctuation of interest rates has been the main causes for the collapse in the housing market in 2007-2008 (Mohd Yusof et al. 2016). Hence, the presence of entire crisis leads toward a question about the effectiveness of RMPs used by banks. Despite of this, Basel Accord (1999) stated that credit risk is the largest source of risk in banking problems. As argued by Jahwari and Khan (2016), the expansion of bank lending activities not only led to higher credit risk but also makes banks more vulnerable to solvency risk. In addition, the digitalization of banking 
institutions' business operations has increased exposure to cyber threats and data breaches. As an example, a major airline carrier experienced a data breach where the hackers obtained over 244,000 credit card details and charged between US\$9 and US\$50 for each card's information in the Dark Web, resulting estimated takings of US\$12 million in 2018 (KPMG's Global Banking Fraud Survey 2020).

Good RMPs lead to a healthier financial performance of IBIs. According to Wang et al. (2018), weaker RMPs could signal poor control mechanisms that affects bank's performance. Therefore, effective RMPs are crucial to sustain business growth and continuous profit improvement of the IBIs. Even though RMPs in IBIs is not a new activity, this issue remains a major concern given the nature and unique characteristics of the risks faced by these institutions along with the limited ways available to them in providing funds using combinations of permissible Islamic modes of financing (Makiyan 2008). But some argued that risk management would significantly affect Islamic banking performance and profitability due to need allocate more resources especially in the greater risk mitigation requirements (Sundararajan \& Errico 2002). Recognizing this reality and the need for a comprehensive approach to addressing bank risk management, the Basel Committee on Banking Supervision (BCBS) has adopted the Basel I, Basel II and Basel III to address the issue. However, IBIs should ensure the risk management approaches being adopted not to be contradicting with the Shariah principle (Khan \& Ahmed 2001).

Therefore, to construct a proper systematic literature review, this study was guided by two (2) research questions developed based on PICOC Framework (Petticrew \& Roberts 2006). In this regard, the authors have included four (4) main aspects in the review which are Islamic banking institutions $(\mathrm{P})$, risk management practices (I), performance $(\mathrm{O})$ and risk management $(\mathrm{C})$, which then guide the author to develop the research questions: (1) what are the risk management practices by Islamic banking institutions?; and (2) what are the effects of the risk management practices on the performance of Islamic banking institutions? Hence, guided by the above research questions, this study aims to systematically review the risk management practices and performance of Islamic banking institutions. Meanwhile, the specific objectives of this study are: (1) to identify risk management practices in Islamic banking institutions; and (2) to analyze the effects of the risk management practices on the performance of Islamic banking institutions. Risk management practices (RMPs) are important for Islamic banking institutions (IBIs) mainly because they represent the risk exposures that may affect their financial stability. The fact that RMPS is not a new activity in IBIs but still attract significant numbers of studies indicate the relevancy of the subject matter. For instance, weak risk management will hamper
IBIs' performance and eventually the stakeholders and industry at large. This study focused on IBIs as these institutions are riskier than conventional banking in terms of the unique risks which are more complicated for the Islamic banking system than the conventional (Abdul Rahman et al. 2012). Subsequently, this study also focused on the RMPs and performance of IBIs because better RMPs are considered to lead the healthier IBIs, which reflect on the bank's financial performance (Rauf \& Irzath 2016).

Many studies (e.g., Abdul Rahman et al. 2014, 2016; Khattak 2013; Khalid \& Amjad 2012; Hassan 2009; Hussain \& Al-Ajmi 2012; Muhammad 2016; Mohd Ariffin \& Kassim 2014; Rosman \& Abdul Rahman 2013; Uddin 2015; Ahmad et al. 2013) have been discussed on RMPs in IBIs. However, most of the past studies only concentrated in certain countries (e.g., Malaysia, Pakistan, Cross-countries) and the studies failed to recognize the different approaches in risk management used by IBIs for unique risks. Furthermore, studies on the effect of the practices on IBIs' performance were still lacking and most of the performance measures used was profitability measures only. Nonetheless, the systematic literature review (SLR) in this regard in the field of Islamic banking is still lacking. Our paper differs from existing literature survey that have focused on factor such as bank risk-taking behavior, for example, (Mairafi et al. 2018) and development in risk management in Islamic Finance (Al-Rahahleh et al. 2019). However, these reviews are not systematic, broad and comprehensive and none of the aforementioned studies focused on the RMPs which are the key driver of banking performance as well as their stability. Therefore, this study aims to fill the gap in the literature by providing an insight for the policy makers to develop understanding regarding RMPs not only for financial and non-financial risks but also for unique risks and they also enabling to know how these practices influences financial performance of IBIs by way of SLR. This study will be great for the manager, especially at the time of framing risk management strategies.

The organization of this paper as follows: The second section briefly explains the methodology used in analyzing the review data. The third section summarize the results and analysis, follow by the depth and overall findings and discussion based on the results in the fourth section. Finally, this paper closes with conclusion and recommendation for future research.

\section{Methodology}

\section{SYSTEMATIC LITERATURE REVIEW}

This study employs qualitative systematic literature review (SLR) as the method of research to evaluate existing research based on the research questions. A systematic review is a technique systematically used by identifying, 
selecting, collecting and critically analyzing the data from all relevant past literatures included in the review to identify the findings of the SLR. According to Higgins et al. (2011), it may or may not be used to summarize and analyze the results of included studies. The advantages of using SLR are it can increase the transparency of article retrieving process, provide research objective that can control research bias and also this study can justify the research gap from the previous studies based on their recommendations for future research depending on how the author regressing their search string that have been used in their study (Mohamed Shaffril et al. 2018). More precisely, in this section, the study explains five (5) subsections which are PRISMA, resources, systematic review process (identification, screening, and eligibility), quality appraisal as well as data abstraction and analysis.

\section{PREFERRED REPORTING ITEMS FOR SYSTEMATIC REVIEWS AND META-ANALYSES}

This SLR was guided by Preferred Reporting Items for Systematic Reviews and Meta-Analyses (PRISMA). PRISMA is not only used in the systematic review analysis, but also can used in other reporting views as a clear guideline to identify the objective of the research. Authors can improve their article writing by using PRISMA checklist. According to Liberati et al. (2009), PRISMA statement consists of a 27-item checklist and four-phase diagram. This study adapted some checklist because not all the 27 items were suitable to be followed in this paper due to the nature of the study field. By using PRISMA, it can help to get a suitable research question and clarify the items that can be included and excluded for the study. Furthermore, it can use a big database to be examined within limited time (Sierra-Correa \& Cantera Kintz 2015). Other than that, the scope of the study can be focused and the findings are transparent without including bias information when reporting a SLR.

\section{RESOURCES}

This study utilized four (4) main online journal databases namely, Web of Science, Scopus, Dimensions and Google Scholar, comprised of four (4) journal publishers i.e., Science Direct, Emerald Insight, Sage and Wiley Online Library. Even though Halevi et al. (2017) stated several weaknesses of Google Scholar especially on the quality, scholars such as Haddaway et al. (2015) highlighted the strength of Google Scholar as a supporting database in retrieving data for review. These chosen databases were related with the current nature of study, contain more articles and widely coverage. For example, Scopus is a wide-ranging citations and abstract databases of peerreviewed literature from 24,600 active titles, 194,000 books and 5000 publishers in the worldwide (Elsevier 2019). It contains indexed journal and comprises robust citation and diversification of fields that can help researchers to identify the gap for a new study. Meanwhile, Web of Science is a comprehensive platform consist of more than 33,000 journals with coverage above 256 disciplines of the nature of study including subjects related to environmental studies (Web of Science Group 2019).

Hook et al. (2018) stated that Dimensions is inclusive; it includes all types of documents in the publication index including book and chapter in book. It also provides new search information and comprehensive data infrastructure that can empowers users to explore more connections between a wide ranges of research data. Google Scholar is also used in the review as it is freely accessible searching database that allows users to access information and cross reference with other sources even though sometimes information would require a payment or login to access full-text information (Hoseth 2011).

\section{SYSTEMATIC REVIEW PROCESS}

Three (3) stages were involved in the systematic review process i.e., identification, screening and eligibility. The search strings on eight (8) electronic journal databases were performed in March 2020.

\section{IDENTIFICATION}

The first stage identified focus on the title, abstract and the appropriate keywords used as searching strategies of the selected databases. Relying on research questions, similar terms used by past studies and thesaurus, dictionaries, encyclopedia, keywords suggested by Scopus and expert opinion related to RMPs and performance of IBIs, so this study have considered to use the keyword for the search terms were "risk", "risk management" and "Islamic". Then, this study runs the identification process in enriching the main keywords used in the studies. The result of this effort has been transformed into search string were demonstrated in Table 1. From the search string used in retrieving the previous studies, a total of 2023 articles were successfully retrieved from eight journal databases. 
TABLE 1. Keywords and searching information strategy

\begin{tabular}{|c|c|c|}
\hline Online Journal Databases & Search String/Keywords Used & Results \\
\hline Scopus & $\begin{array}{l}\text { TITLE-ABS-KEY((“banking risk" OR “financial risk" OR “non-financial risk” OR “unique } \\
\text { risk" OR "general risk” OR “generic risk”) AND ("risk manag*” OR "risk mitigat*”) AND } \\
\text { (islamic OR s*ariah OR s*aria OR s*ari'ah)) }\end{array}$ & 24 \\
\hline Web of Science & $\begin{array}{l}\mathrm{TS}=((\text { (banking risk" OR "financial risk" OR "non-financial risk" OR "unique risk" OR } \\
\text { "general risk" OR "generic risk") AND ("risk manag*” OR "risk mitigat*”) AND (islamic } \\
\text { OR s*ariah OR s*aria OR s*ari'ah)) }\end{array}$ & 14 \\
\hline Dimensions & $\begin{array}{l}\text { ((“banking risk" OR "financial risk" OR "non-financial risk" OR "unique risk" OR "general } \\
\text { risk" OR "generic risk") AND ("risk manage” OR "risk management” OR "risk mitigate" OR } \\
\text { "risk mitigation") AND (islamic OR syariah OR shariah OR syaria OR sharia OR shari'ah } \\
\text { OR syari’ah)) }\end{array}$ & 26 \\
\hline Google Scholar & $\begin{array}{l}\text { "banking risk" OR "financial risk" OR "non-financial risk" OR "unique risk" OR "general } \\
\text { risk" OR "generic risk" "risk manage*” OR "risk mitigate*" islamic OR syariah OR shariah } \\
\text { OR syaria OR sharia OR shari'ah OR syari'ah }\end{array}$ & 414 \\
\hline SAGE & $\begin{array}{l}\text { ((“banking risk" OR "financial risk" OR "non-financial risk" OR "unique risk" OR "general } \\
\text { risk" OR "generic risk") AND ("risk manage” OR "risk management” OR "risk mitigate" OR } \\
\text { "risk mitigation") AND (islamic OR syariah OR shariah OR syaria OR sharia OR shari'ah } \\
\text { OR syari’ah)) }\end{array}$ & 46 \\
\hline Science Direct & $\begin{array}{l}\text { ((“banking risk" OR “financial risk" OR “non-financial risk” OR "unique risk” OR "general } \\
\text { risk" OR "generic risk”) AND ("risk management” OR "risk mitigation”) AND (islamic OR } \\
\text { s*ariah OR s*aria OR s*ari'ah)) }\end{array}$ & 4 \\
\hline Emerald Insight & $\begin{array}{l}\text { ((“banking risk" OR "financial risk" OR “non-financial risk” OR "unique risk" OR "general } \\
\text { risk" OR "generic risk") AND ("risk manag*” OR "risk mitigat*”) AND (islamic OR s*ariah } \\
\text { OR s*aria OR s*ari'ah)) }\end{array}$ & 1180 \\
\hline Wiley Online Library & $\begin{array}{l}\text { ((“banking risk" OR “financial risk” OR “non-financial risk” OR "unique risk” OR “general } \\
\text { risk” OR "generic risk") AND (“risk management” OR "risk mitigation”) AND (islamic OR } \\
\text { s*ariah OR s*aria OR s*ari'ah)) }\end{array}$ & 315 \\
\hline
\end{tabular}

\section{SCREENING}

The second stage was screening process. For the screening purposes, since different situation stimulates different needs, this study decided to rely on justification by Kitchenham and Charters (2007), who emphasized on the important of selection criteria that able to guide and assist the authors to answer the research questions in the study. The inclusion and exclusion criteria selected by the authors were detailed in Table 2.

The first criterion was document type. This study selected only article journals as primary sources which means systematic review journals, book, chapter in book, book series and conference proceeding were all excluded. The second criterion was language. To avoid confusing and difficulty in translating, this study focused only on articles in English as suggested by Okoli (2015) who emphasize select the language that we understand. Furthermore, Patino and Ferreira (2018) suggested reviewing articles that can only reach our understanding. Hence, after thoroughly screening process, 420 duplicates articles were removed, whilst the remaining articles (852 articles) were assessed for eligibility process.

TABLE 2. Inclusion and exclusion criteria

\begin{tabular}{lll}
\hline Criteria & Inclusion & Exclusion \\
\hline Document type & Journal (research articles) & Review articles, books, chapters in book, book \\
& & series, conference proceedings \\
Language & English & Non-English \\
\hline
\end{tabular}




\section{ELIGIBILITY}

Eligibility is a manually process to include or exclude the remaining articles (from screening process) based on the criteria determined by the authors. At this stage, the authors examined thoroughly the title followed by the abstract and contents of all articles to ensure that they were in line with research questions to achieve the objectives of the study. As a result, a total of 813 articles were removed and a total of 39 final articles were ready to be analyzed (see, Figure 2).

\section{QUALITY APPRAISAL}

To assure that all selected articles are in good shape in terms of quality, the second and third authors served as experts for quality appraisal. The second stage assessment included in-depth reading of the following sections: introduction, methodology, findings, discussion and conclusion (full articles). In addition, the first author independently reviewed the 39 final articles, which were monitored by other authors. During the process, the authors decided to justify that all 39 articles were in good quality and all of them were included in the review i.e., primary studies.

\section{DATA ABSTRACTION AND ANALYSIS}

This study reviewed the selected previous literature in the review process and extracted all the information as a raw material before synthesizing them. Whittemore and Knafl (2005) argued that the best way to synthesize a mix research design (qualitative and quantitative) is by performing a qualitative analysis, while Flemming et al. (2018) claimed that the best qualitative analysis to cater a mix review is thematic analysis.

Any data from the selected previous literature in the review process that answered the research questions were abstracted and placed in the table. After that, the authors manually performed the thematic analysis, which is identified themes and sub-themes related to noting patterns that existed within the data abstraction. Eventually, a total of 16 themes and 17 sub-themes were created. The themes that have been organized were reviewed by an expert to validate the quality of the thematic analysis of this study.

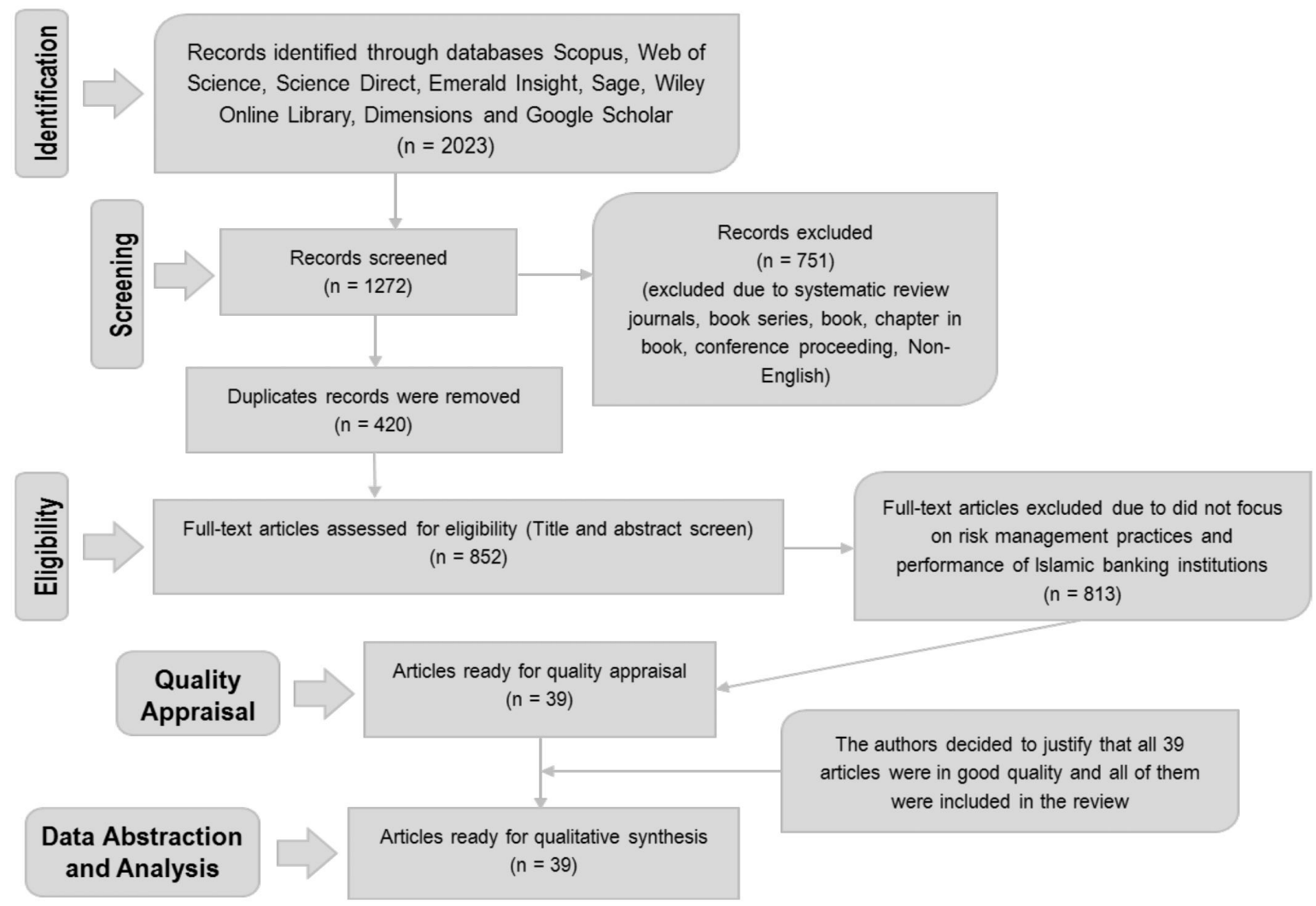

FIGURE 2. Flowchart of PRISMA

Source: Adapted from Moher et al. (2009) and Mohamed Shaffril et al. (2019). 


\section{Results And Analysis}

\section{GENERAL FINDINGS}

Through the thematic analysis developed from research questions and efforts by the authors, 16 themes and 17 sub-themes evolved from the results of SLR concerning the RMPs and performance of IBIs. The result provided a comprehensive analysis of the body literature at essential aspects, namely research methodologies, year of publication and countries where studies were conducted and finally, the authors report them as demonstrated in Figures 3, 4 and 5.

\section{FREQUENCY OF PUBLISHED ARTICLES ACCORDING TO RESEARCH METHODOLOGIES}

With regard to research methodologies undertaken by the primary studies (refer, Figure 3), there were 28 articles with quantitative approach (Rosman \& Abdul Rahman 2015; Daher et al. 2015; Kadhim et al. 2019; Fakhrunnas \& Imron 2019; Archer et al. 2010; Khattak et al. 2013; $\mathrm{Ng}$ et al. 2017; L'Huillier et al. 2018; Akhtar \& Jahromi 2015; Farooq \& Zaheer 2015; How et al. 2005; Ismail \& Ahmad 2006; Zakaria \& Ismail 2008; Diaw \& Mbow 2011; Masood \& Fry 2012; Pellegrina 2012; Mohd Yusof et al. 2011; Ismal 2010; Alkhouri \& Arouri 2019; Ghassan \& Guendouz 2019; Rauf \& Irzath 2016; Al-Tamimi \& Al-Mazrooei 2007; Mohd Ariffin \& Kassim 2011; 2014; Hussain \& Al-Ajmi 2012; Abdullah et al. 2011; Abdul Rahman et al. 2014; Zubairi \& Ahson 2015). Meanwhile, there were 11 articles with qualitative approach (Chazi \& Syed 2010; Mohammad 2013; Crane \& Leatham 1993; Siddiqui 2008; Rosly \& Mohd. Zaini 2008; Djojosugito 2008; Magalhaes \& Al-Saad 2013; Khan \& Bhatti 2008; Kamil et al. 2010; Dolgun et al. 2020; Khalid \& Amjad 2012).

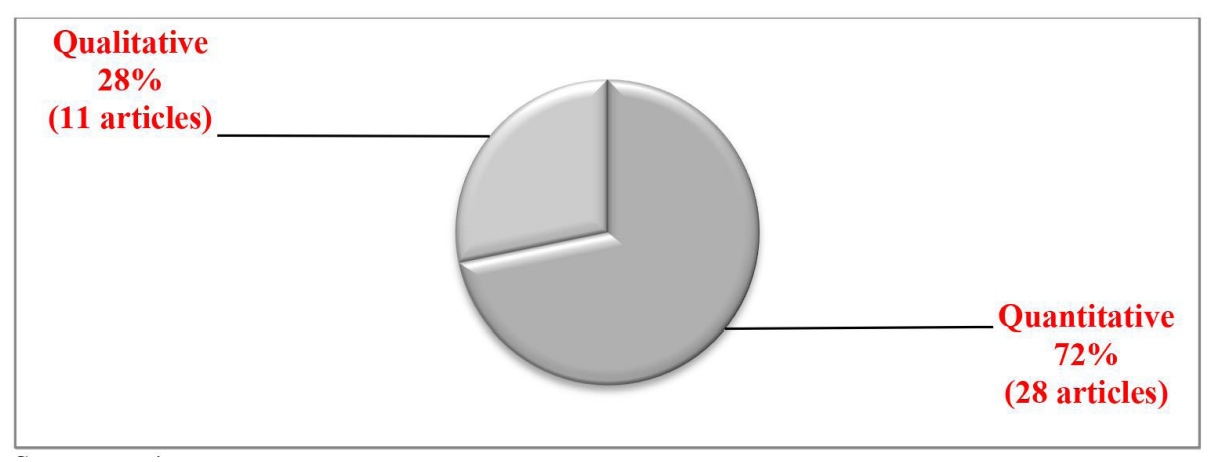

FIGURE 3. Research Methodologies

Source: Authors' Own (2020)

FREQUENCY OF PUBLISHED ARTICLES ACCORDING TO YEAR

As showed in Figure 4, an article was published in 2020 (Dolgun et al. 2020), followed by four (4) articles in 2019 (Fakhrunnas \& Imron 2019; Ghassan \& Guendouz 2019; Alkhouri \& Arouri 2019; Kadhim et al. 2019), and one (1) article each in 2018 (L'Huillier et al. 2018), 2017 (Ng et al. 2017), and 2016 (Rauf \& Irzath 2016) respectively. There were five (5) articles were published in 2015 (Rosman \& Abdul Rahman 2015; Akhtar \& Jahromi 2015; Daher et al. 2015; Farooq \& Zaheer 2015; Zubairi \& Ahson 2015), two (2) articles in 2014 (Mohd Ariffin \& Kassim 2014; Abdul Rahman et al. 2014), and three (3) in 2013 (Magalhaes \& Al-Saad 2013; Khattak et al. 2013; Mohammad 2013), four (4) in 2012 (Hussain \& Al-
Ajmi 2012; Khalid \& Amjad 2012; Masood \& Fry 2012; Pellegrina 2012). There were also four (4) articles were published in 2011 (Diaw \& Mbow 2011; Mohd Yusof et al. 2011; Abdullah et al. 2011; Mohd Ariffin \& Kassim 2011) and 2010 (Kamil et al. 2010; Archer et al. 2010; Ismal 2010; Chazi \& Syed 2010) correspondingly and five (5) articles in 2008 (Zakaria \& Ismail 2008; Siddiqui 2008; Rosly \& Mohd. Zaini 2008; Djojosugito 2008; Khan \& Bhatti 2008). Finally, there was one (1) article published in 2007 (Al-Tamimi \& Al-Mazrooei 2007), 2006 (Ismail \& Ahmad 2006), 2005 (How et al. 2005) and 1993 (Crane \& Leatham 1993) separately. It is worth noting that studies on RMPs have increased significantly in 2008, 2015 and 2019. 


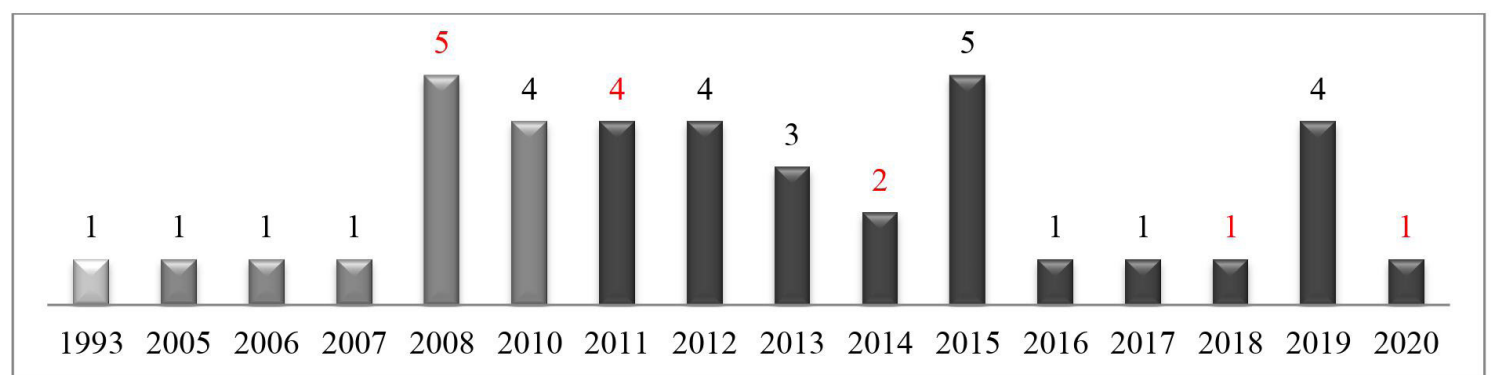

FIGURE 4. Year of Article Publication Source: Authors' Own (2020)

FREQUENCY OF PUBLISHED ARTICLES ACCORDING TO COUNTRY SETTING

As depicted by Figure 5, as of 2010, Malaysia dominated the research setting for studies on RMPs and IBIs (7) $(\mathrm{Ng}$ et al. 2017; How et al. 2005; Zakaria \& Ismail 2008; Mohd Yusof et al. 2011; Mohd Ariffin \& Kassim 2011; 2014; Abdullah et al. 2011), followed by six (6) studies on Pakistan (Khattak et al. 2013; Farooq \& Zaheer 2015; Siddiqui 2008; Khalid \& Amjad 2012; Masood \& Fry 2012; Zubairi \& Ahson 2015) and two (2) on Indonesia (Fakhrunnas \& Imron 2019; Ismal 2010). There were also eleven (11) primary studies on cross-countries analysis (Rosman \& Abdul Rahman 2015; Archer et al. 2010; L'Huillier et al. 2018; Chazi \& Syed 2010; Mohammad
2013; Pellegrina 2012; Akhtar \& Jahromi 2015; Diaw \& Mbow 2011; Magalhaes \& Al-Saad 2013; Khan \& Bhatti 2008; Abdul Rahman et al. 2014). Other than that, there was one (1) study on Iraq (Kadhim et al. 2019), GCC (Alkhouri \& Arouri 2019), United States (Crane \& Leatham 1993), Turkey (Dolgun et al. 2020), Saudi Arabia (Ghassan \& Guendouz 2019), Sri Lanka (Rauf \& Irzath 2016), Bahrain (Hussain \& Al-Ajmi 2012) and United Arab Emirates (Al-Tamimi \& Al-Mazrooei 2007) respectively. It is important to point out that studies on RMPs were concentrated in countries with established IBIs such as Malaysia, Pakistan and Indonesia, which signified the availability of data among the most important factor for research.

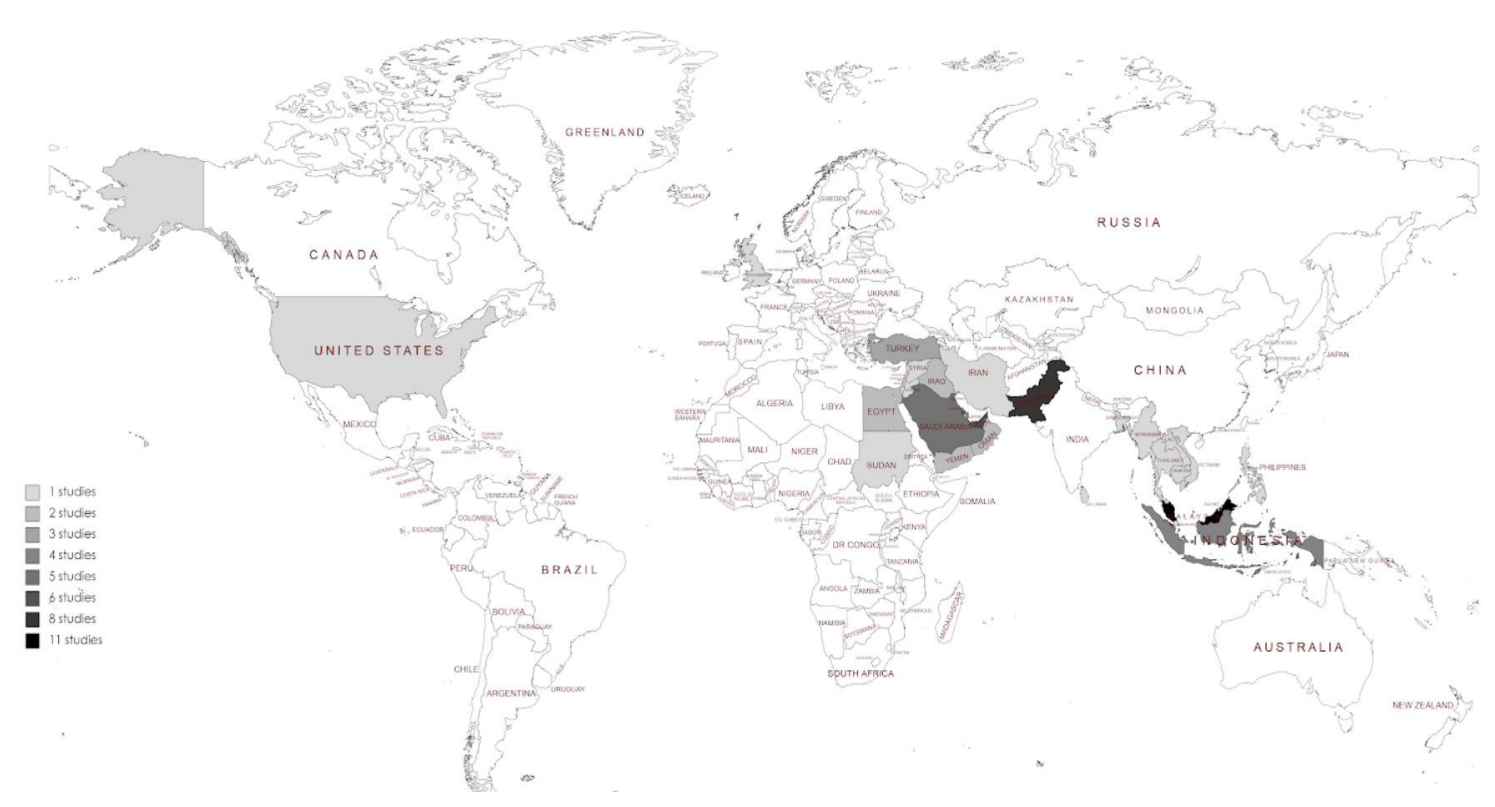

\begin{tabular}{|c|c|c|c|c|c|c|c|c|c|c|c|c|}
\hline Country & Malaysia & Pakistan & $\begin{array}{c}\text { Cross- } \\
\text { countries }\end{array}$ & Indonesia & Iraq & Turkey & $\begin{array}{c}\text { Saudi } \\
\text { Arabia }\end{array}$ & Bahrain & GCC & US & UAE & $\begin{array}{c}\text { Sri } \\
\text { Lanka }\end{array}$ \\
\hline Article & 7 & 6 & 11 & 2 & 1 & 1 & 1 & 1 & 1 & 1 & 1 & 1 \\
\hline
\end{tabular}

FIGURE 5. Country Setting of Studies on RMPs and IBIs

*Note: Exclude five (5) general studies on RMPs conducted in Asian countries (Daher et al. 2015; Ismail \& Ahmad 2006; Rosly \& Mohd. Zaini 2008; Djojosugito 2008; Kamil et al. 2010).

Source: Authors' Own based on mapchart.net (2020) 
THEMATIC ANALYSIS

In the present study, thematic analysis is used to develop appropriate themes and sub-themes. To conduct thematic analysis, the first phase is data compilation. In this phase, the authors manually and thoroughly analyzed the selected articles and synthesis them into a group. Then, in the second phase, the authors have independently decided the thematic findings and this process is monitored by the second and third authors to ensure the transparency and reviewed by an expert to validate the quality of thematic analysis in the current study. Eventually, this process produced a number of themes and sub-themes.

\section{MAIN FINDINGS}

1. Risk Management Practices In Islamic Banking Institutions

Risk management is the process of risk exposure are identified, assessed, analyzed, quantified, mitigated, monitored and controlled. In the Al-Qur'an, risk management has been stated in Surah Yusuf, Verse 67 as the command for a man to take precautionary measures against any risks. Moreover, in the Hadith, Prophet Muhammad (PBUH) also advised Muslims not to be passive, but also instructs to take suitable action to minimize losses and calamities; the Prophet Muhammad (PBUH) once asked an Arab Bedouin to tie his camels before placing trust in Allah for its protection. Hence, it is mandatory to risk management committee in IBIs to have a strategic planning to identify, control and manage or mitigate anticipated risk.

In this regard, RMPs is probably considered the most important aspect of risk management (Al-Tamimi \& AlMazrooei 2007). Even if the staff and board management of IBIs clearly understand risk and risk management and using sophisticated methods in risk assessment and analysis, it still does not guarantee that there have an effective RMPs are followed by them (Hussain \& Al-Ajmi 2012). Sound RMPs are critical important nowadays to mitigate the operational and strategic problem in IBIs. There are several bodies that regulate and govern the guiding principles on the risk management for banking sector, which are Bank Negara Malaysia (BNM), Basel Committee on Banking Supervision (BCBS) and Islamic Financial Services Board (IFSB).

As reference to BCBS $(1999 ; 2001 b ; 2011 ; 2019)$ and $\operatorname{BNM}(2001 ; 2012 ; 2013)$ concerning RMPs, there are three (3) important principles are used for the best and sound management and supervision of risk. These principles are (1) governance; appropriate overview by the board of directors (BODs) and management; (2) risk management process; and (3) internal controls. These principles which a banking institution should adopt and are required to implement in addition to the best practices. According to BNM (2001), the board should be aware and must also ensure the proper oversight of the management of risk of the banking institutions. Management are responsible for implementing and establishing policies which approved by the Board and developing policies and procedures for identifying, measuring, monitoring and controlling risks. Internal auditors must provide an ongoing focus on the internal control systems and review of risk management process.

The IFSB (2005) also provide the general requirement of RMPs to prepare a comprehensive risk management and reporting process. These include appropriate board and senior management oversight, to identify, measure, monitor, report and control relevant categories of risks, as well as to hold adequate capital against these risks. Furthermore, the process should consider appropriate steps to comply with Shariah principles and rules and to ensure the adequacy of relevant risk reporting to the supervisory authority.



FIGURE 6. The Principles of RMPs 
To achieve objective of identifying RMPs in IBIs, there is a need to have a comprehensive understanding of the measurement of these practices. To measure RMPs, five (5) important principles in reference to the BCBS $(1999 ; 2001 b ; 2011 ; 2019)$ and BNM $(2001 ; 2012 ; 2013)$ were used (see, Figure 6). The evolution and details five (5) areas of principles covering of three (3) principles of sound risk management as mentioned before.

The five (5) principles of RMPS are risk management environment, policies and procedures, risk measurement, risk mitigation, risk monitoring and internal control. Those principles reflect level of risk that is undergone by the Islamic banks. It shows a result of what extent the IBIs is vigilant in terms of taking necessary action. Healthy risk practices will give better performance of IBIs. Then, specific items assessing each area of RMPs in IBIs are further refined based on thematic analysis as demonstrated in TABLE 3. After that, all these five principles are then link with the performance of IBIs.

\subsection{Risk Management Environment, Policies And Procedures}

Regarding the risk management environment, policies and procedures practices adopt by IBIs, six (6) main themes are being developed, namely regulation (15), management policy (2), role board of directors (2), role of religious branding (1), audit and valuation on investment (1) and consumer education (1) along with the emerging four (4) sub-themes.

\subsubsection{Regulation}

Policy makers or regulators can improve the performance of IBIs by setting corrective regulations for best RMPs which result in improving the stability and efficiency of IBIs. Several studies reported that the regulation practiced to manage the risks and maintain the development of the institutions. Under this theme, four (4) sub-themes emerged, namely, capital adequacy ratio (8), application of Basel Accord (4), net stable funding ratio (2) and liquidity coverage ratio (1).

\section{a. Capital adequacy ratio (CAR)}

Implementation minimum capital requirement is critically important to ensure that banks' risk exposure is backed by the minimum adequate amount of capital (cushion) that can continuously absorb losses (Masood \& Fry 2012). Furthermore, CAR is one of the most factors to enhance the financial stability of the banks (L'Huillier et al. 2018). Islamic banks have a lower risk and show a better position in terms of gross revenue and leverage ratio as measured by the capital adequacy (Chazi \& Syed 2010). Despite this, the study of Siddiqui (2008) found that some Islamic banks have already met or exceeded industry standard in CAR, which means if the ratio is more or equal to 8 percent (Khattak et al. 2013). In addition, How et al. (2005) mentioned that bank capital is statistically related to the liquidity risk. As argued by Pellegrina (2012) and Daher et al. (2015), Islamic banks that have more capital tend to adopt safer policies than their conventional counterparts.

\section{b. Application of Basel Accord}

Application of Basel Accord in emerging countries is generally well received due to its purposes in managing risks and improving capital administration (Masood \& Fry 2012). Studies by Khattak et al. (2013) found that implementation of Basel generally will increase the efficiency and RMPs in IBIs. Furthermore, application of Basel regulation will be one of the factors in enhancing stability of banks (L'Huillier et al. 2018). However, Siddiqui (2008) suggest that central bank must take an action to create equal competition for Islamic banks as well as not burden them with stringent Basel liquidity and capital requirement.

\section{c. Net stable funding ratio (NSFR)}

Net stable funding ratio is a minimum standard that requires banking institutions to maintain adequate liquidity as a stable funding profile to support their offbalance sheet activities and their assets. This funding reduces the probability that the liquidity position of banking institutions will be severely eroded by material interruption to its regular sources of funding. According to L'Huillier et al. (2018), the net stable funding ratio has the capability to improve financial stability of Islamic banks. Meanwhile, Siddiqui (2008) stated that maintain adequate liquidity requirements by Islamic banks will demonstrated good performance and better risk management.

\section{d. Liquidity coverage ratio (LCR)}

Implementing the liquidity coverage ratio for Islamic banks because they hold more cash than it should. LCR refers to a quantitative requirement introduced by BNM to ensure banking institutions have adequate high-quality liquid assets (HQLA) to withstand a severe liquidity stress problem within 30 days at the consolidated and entity level. In addition, LCR complemented by the NSFR. Dolgun et al. (2020) suggest a maximum liquidity ratio for Islamic bank. Implementing a cap to the LCR will force discipline on Islamic banks to manage their assets properly and encourage their financial intermediation to the real sector especially in protecting the interest of investment account holders. Although cash outflows from investment accounts on the right side of Islamic banks' balance sheet are included in short-term projection, they should not be included in the denominator of LCR. 


\subsubsection{Management policy}

The strengthening of management policy is necessary as it enhances Islamic banks efficiency, especially in the crisis period. According to Fakhrunnas and Imron (2019), policy maker must issue different policy for different size of Islamic banks by looking at Islamic banks capability to manage the different type of risks that will affect Islamic banking performance. For example, Islamic banks set an effective liquidity risk management policy to maintain their solvency. To a large extent, this policy must include both qualitative and quantitative factors (Mohammad 2013).

\subsubsection{Role board of directors}

According to Mohd Ariffin and Kassim (2014), board of directors (BoD) play an important role for approving the overall policies and ensuring that management is carrying out its risk management responsibilities. Furthermore, they also have responsibility for maintaining the performance of the banks on a stable level and keep the image of IBIs loyal among all stakeholders (Rauf \& Irzath 2016).

\subsubsection{Role of religious branding}

Religious branding pertaining to the framework of the IBIs plays a crucial role in shaping the future of risk management strategies. In other words, 'religious branding' rather than other observable bank characteristics, might have helped Islamic banking branches travel better in the face of financial panic. It is worth to mention that depositors would not abandon IBIs for religious reasons during a financial panic. Subsequently, religious branding can attract (rather than lose) depositors during financial panics to the Islamic branches of banks that offer both conventional and Islamic operations (Farooq \& Zaheer 2015).

\subsubsection{Audit and Valuation on investment}

Rosman and Abdul Rahman (2015) claimed that frequent review on the procedures and policies of profit-sharing investment was important to identify and monitor the risks related with investment in Islamic banks. Hence, they need to perform audit and valuation on their investment.

\subsubsection{Consumer education}

Mohd Yusof et al. (2011) stated that consumer education is vital as part of RMPs by Islamic banks. In other words, customer knowledge in Islamic banking services has affected the customers' perception and their choice criteria. This is because there is possibility that customers opt to choose the products based on conventional if Islamic banks not providing necessary and enough knowledge for customer when it is in fact required.
Therefore, consumer education plays an important role to ensure that new Islamic banking products are well received by the customers.

\subsection{Risk Measurement}

Moving on to the risk measurement practices by IBIs, we found that they are still new in banking sector, and they have insufficient resources and system to adopt more technically advance techniques for risk measurement. For risk measurement practices, two main themes have been developed, namely value at risk (2) and stress testing (1).

\subsubsection{Value at risk (VaR)}

According to Abdullah et al. (2011), value-at-risk (VaR) approach is used for measuring the market risk. It is used by both financial and non-financial institutions to estimate exposure to financial risks, set trading position limits and others. However, the last global financial crisis 2007-2008 highlighted some of the weaknesses of this measure as a measure of market risk whereby, there is lack of a liquidity parameter in methodologies used to compute VaR significantly decreased the effectiveness of this measure. In this regard, $\mathrm{Ng}$ et al. (2017) suggest that IBIs need to improve VaR in measuring market risk to produce reliable and robust estimates results.

\subsubsection{Stress testing}

It should be noted that the bank has depended on minor activities to achieve return. Hence, it is possible to apply stress testing to Islamic banks as presented by Basel's committee. Studies by Khadim et al. (2019) have shown that designing new stress testing scenarios especially for minor operational activities and bank revenues also equation of cash flows is needed if the post-shock capital adequacy averages have been exceeded the minimum limits as prescribed by Basel's committee. Despite this, banks can use stress testing to manage credit risk as so as in setting limits and monitoring by considering interest rate, business cycles and other market movements.

\subsection{Risk Mitigation}

Under this principle, six (6) main themes evolved to describe the risk mitigation practices by the IBIs. The main themes are instruments (10), diversification (5), empowerment the quality of debt (6), income smoothing (3), increase the involvement in fee-based activities (1) and long-term project financing (1), along with the emerging 17 sub-themes.

\subsubsection{Instruments}

More specifically, this section discusses other instruments which revolves around six (6) sub-themes, namely securitization (4), sukuk (2), murabahah (1), commodity 
murabahah (1), Islamic stocks (1) and government investment issues (1).

\section{a. Securitization}

How et al. (2005) found that securitization is statistically significant related to banks' liquidity risk. Securitization is an Islamic instrument used by Islamic banks to cover liquidity shortfall (Mohamad 2013). Meanwhile, Zakaria and Ismail (2008) stated that securitization theoretically could reduce risk as well, decrease banks' degree of risk aversion. As their involvement in the securitization activity increases, the propensity of Islamic banks to lend will decrease. Hence, such on-balance-sheet risk management based on securitization would be feasible alternative for IBIs rather than use conventional banks' risk management tools (Archer et al. 2011).

\section{b. Sukuk}

The fundamental of sukuk is based on tripartite which are Sukuk Originator (Obligor) who holds the assets, Special Purpose Vehicles (SPV) as a separate independent legal entity that obtained the assets and issued sukuk certificate and investor who bought the sukuk. Kamil et al. (2010) claimed that even though sukuk were structured in a similar way with conventional asset-backed securities, but they have different underlying structures, provisions and Shariah compliant which prohibits the received and payment interest. Meanwhile, Khan and Bhatti (2008) argued that the issuance of sukuk would incur risks like interest rate, Shariah compliance, foreign exchange and credit risk. Thus, Kamil et al. (2010) opined that sukuk structures is considered as risk sharing rather than risk shifting, whereby it performs by combining risk-exposure in such a way that they balance each other to some extent. As a result, the overall risk would be less than the total risk individually.

\section{c. Murabahah}

Ismal (2010) in his study found that volatility of returns (investment risk) of Islamic banks is well managed by the domination of murabahah financing. This is because pre-determined and fixed returns of murabahah contract resulted that the investment risk of Islamic bank financing is relatively under controlled.

\section{d. Commodity murabahah}

Commodity murabahah is the most common instrument for managing the liquidity used by Islamic banks (Mohammad 2013). Customers purchased the commodity on the spot with full payment and then the commodity immediately sold them to the third party on a deferred payment based on murabahah (cost-plus) usually from one week to six months. Hence, this process is usually done in order to absorb or inject funds depends on the needs and demands of financial institutions.

\section{e. Islamic stocks}

Akhtar and Jahromi (2015) in their study reported that there have significant impacts and benefits of Islamic stocks during the early stage of crisis, and this is due to the prohibition derivatives and sub-prime mortgage securities that contribute to the crisis. Due to the prohibition of these activities, Islamic financial institutions are to a certain extent protected from the effects of a collapse in risky securities. The strongest benefits of Islamic stocks were founded in the countries that had a large exposure to sub-prime mortgage investment, such as UK and USA. However, Islamic stocks were affected during the second stage of crisis that marked by a global recession, and they were as prone to decline in consumption, trade, investor sentiment and production.

\section{f. Government investment issues (GIIs)}

Government investment issues refer to government securities issues on Islamic fundamental. Furthermore, GIIs are instruments used by Islamic banks for liquidity purpose. They sold GIIs to the central bank under the various modes of underlying Islamic contracts, normally musyarakah, mudarabah, ijarah and salam to meet their liquidity needs (Mohammad 2013).

\subsubsection{Diversification}

Diversification is one of the ways to mitigate risk. Diversified banks able to manage the risk effectively rather than concentrated banks. In this regard, several studies have focused on this aspect which managed to lead to the emergence of two sub-themes under the diversification theme, namely diversified assets portfolio (3 studies) and diversified investment portfolio (2).

\section{a. Diversified assets portfolio}

Diversified asset affects Islamic banks performance positively as well as adds value to Islamic banks (Alkhouri \& Arouri 2019). Meanwhile, Ghassan and Guendouz (2019) argued that diversification of asset will improves Islamic banks' financial stability. Moreover, investors may reduce their vulnerable to risk by holding a diversified assets portfolio ( $\mathrm{Ng}$ et al. 2017).

\section{b. Diversified investment portfolio}

According to Khattak et al. (2013), it is risky to invest Islamic banks' funds in concentrated or specific sector of the economy as Islamic banks exposed to high risk than their conventional counterparts since their based products on profit and loss sharing principles. Thus, they need to diversify their investment portfolio to protect against possible losses (Crane \& Leatham 1993). 


\subsubsection{Empowerment of the quality of debt}

The next theme is empowerment of the quality of debt, and it can be divided into five (5) sub-themes, namely debt restructuring (2), tightening up credit valuation (1), welldiscipline collection policy (1), high down-payments (1) and higher collaterals (1).

\section{a. Debt restructuring}

According to Djojosugito (2008), the legal risk faced by Islamic banking can be mitigating through employing debt or financing restructuring using documentation to create an arrangement complying with the Shariah requirement. Furthermore, debt restructuring plays an important role for Islamic banking system typically in the case of default where the bankruptcy cost is larger than liquidation of entrepreneur's asset (Ismail \& Ahmad 2006). In addition, it is vital to ensure that economy would not easily succumb by the financial distressed.

\section{b. Tightening up credit valuation}

The application of murabahah financing should largely expose to default or credit risk. Further, Rosly and Mohd. Zaini (2008) argued that this risk can be eliminated by not offering the facility at all or it can simply be minimized by tightening up credit valuation and stringent credit enhancers.

\section{c. Well-discipline collection policy}

Credit risk exposure is a measurement of the maximum potential losses to a lender if the borrower failed to make a payment. However, it is often can be minimized with well-discipline collection policy and prudent lending principles (Rosly \& Mohd. Zaini 2008) to ensure Islamic banking institution's safe, sound and efficient operation.

\section{d. High down-payments}

High down-payment is one of the risk mitigation strategies used by Islamic banks. For example, credit risk attached to instruments likes murabahah financing in the case of counterparty default to pay the debts on time, can be mitigate by made a high down-payment (Rosly \& Mohd. Zaini 2008).

\section{e. Higher collaterals}

Collateral is part of the important securities for Islamic banks to cover credit losses and enhanced the quality of credit by reducing it risk. It also can help banks to mitigate inherent risk in the individual transactions. This argument supports by Rosly and Mohd. Zaini (2008) argued that higher collaterals can control credit risk in murabahah financing.

\subsubsection{Income smoothing}

Islamic banks are concerned on the displaced commercial risk when the depositors decided to withdraw their funds and invest them to another place. This situation forces Islamic banks to use income smoothing (Magalhaes \& Al-Saad 2013) i.e., the use of Profit Equalisation Reserve (PER) and Investment Risk reserve (IRR). The provision for PER is derived from the mudarabah income before the distribution of mudarib's share, while the provision for IRR directly comes from the IAH's income after the mudarib share is allocated. Those reserves are important for Islamic banks to pay a competitive return to IAH when income from their operations does not allow them to do so (Diaw \& Mbow 2011). On the other hand, the utilization of PER appears to attract new depositors, especially IAH as the main sources of funds to the bank (Rosman \& Abdul Rahman 2015). Meanwhile, IRR helps banks to ensure the IAH fund deposits in case of losses.

\subsubsection{Increase the involvement in fee-based activities}

According to Rosman and Abdul Rahman (2015), increasing the bank's involvement in fee-based activities can minimize or reduce the foreign exchange rate risk in Islamic banks such as activities do not involve or expose the banks with fluctuation features.

\subsubsection{Long-term project financing}

According to Siddiqui (2008) in his study shown that Islamic banks need to engage in long-term project financing rather than engage in short-term financing to manage their risk concerning to the good performance and risk management as well as for economic growth. The balance sheets and various performance indicators show that there is evidence that Islamic banks in Pakistan tend to involve in long-term project financing, and as result, these banks have shown good performance with respect to the returns on their assets and equity and demonstrated better risk management and maintained adequate liquidity.

\subsection{Risk Monitoring}

Risk monitoring is useful for cross-checking the effectiveness of the risk management system and help bank to discover mistake at early stage as well as to make sure RMPs are in line (Al-Tamimi \& Al-Mazrooei 2007). As argued by Khalid and Amjad (2012), risk monitoring is the most significance and influencing variable on RMPs. This argument is consistent with Khattak et al. (2013) and Hussain and Al-Ajmi (2012) who report that risk monitoring has a positive and significant effect on RMPs. IBIs are keen to monitor risk especially in their daily operations. They always consider Shariah compliance issue in monitoring process (Abdul Rahman et al. 2014). Hence, Islamic banking has in place Shariah committee 


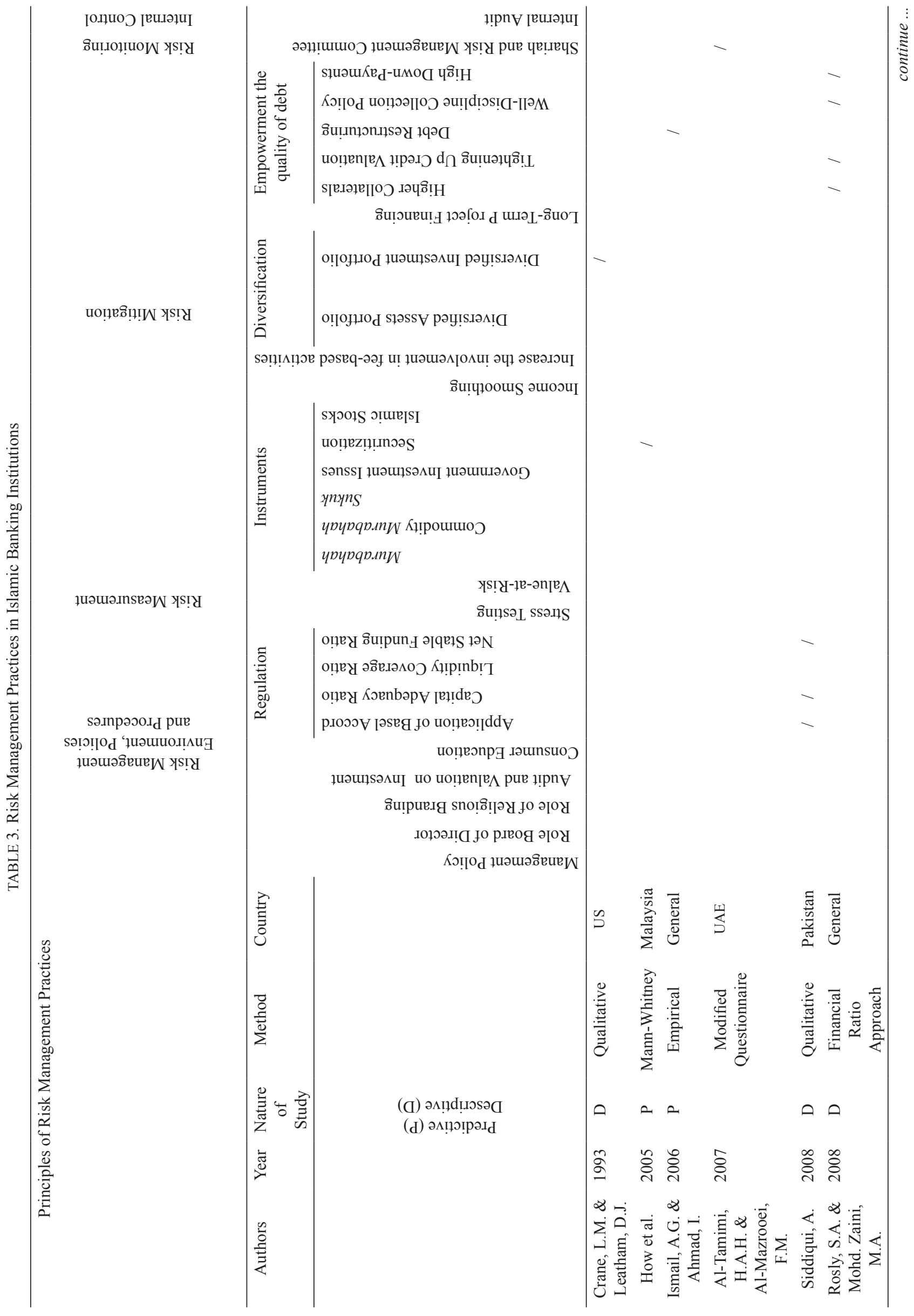




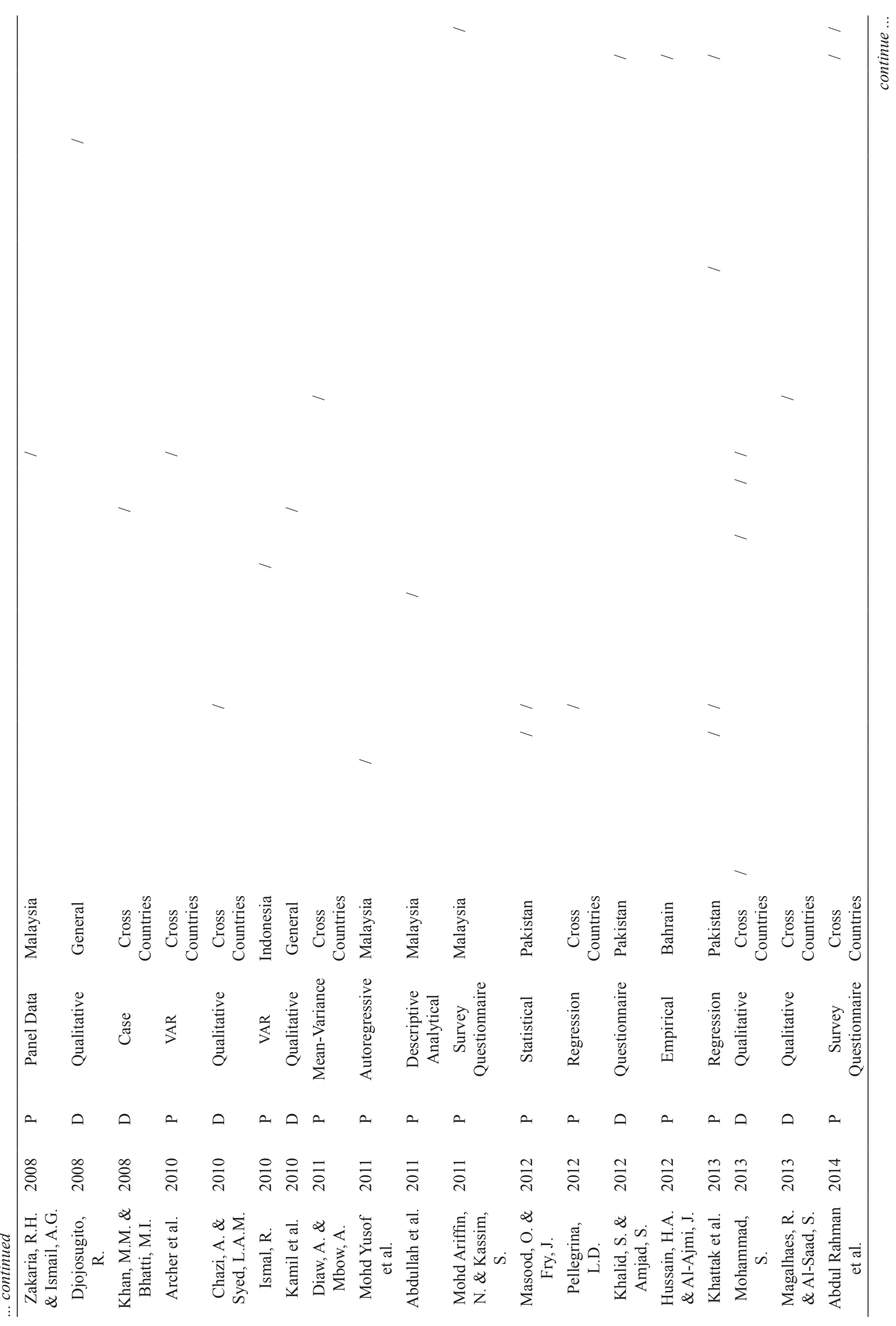




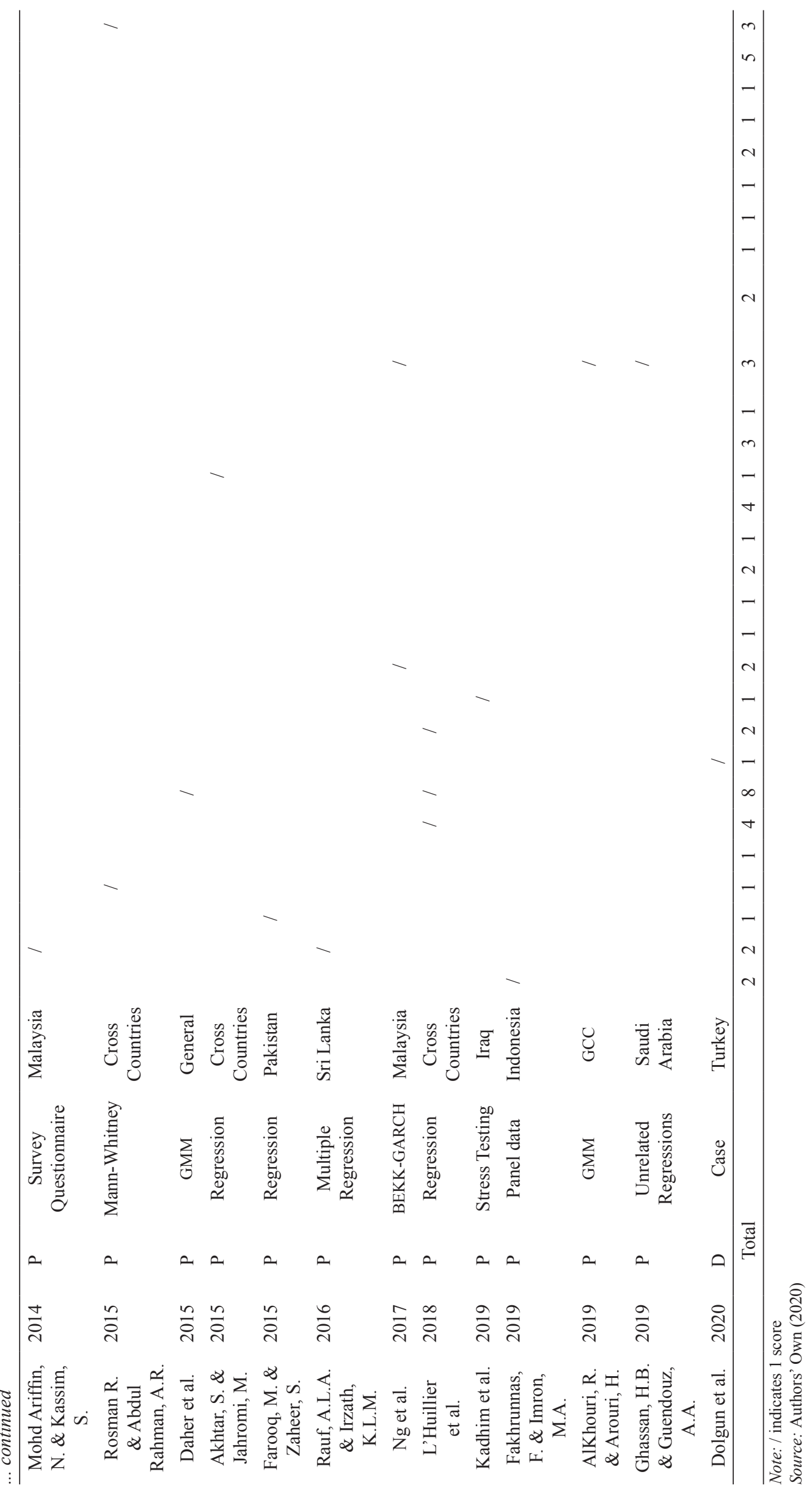


and Risk management committee in the governance structure to perform monitoring and oversight function and also to ensure the soundness and effectiveness of the overall risk management on a bank-wide level.

\subsection{Internal Control}

IBIs currently facing new and unique risks, so management should implement appropriate and best control practices to protect institutions from negative events (Abdul Rahman et al. 2014). According to Mohd Ariffin and Kassim (2011), Islamic banking already has proper internal control of its banking operations. However, the control by the management board is not enough to guarantee that the functioning of risk monitoring system effectively because the board does not have enough time to do a comprehensive control. Therefore, there is a need for independent units to complete internal control and supervision tasks (Rosman \& Abdul Rahman 2015). Then, this task can be done by internal audit as it is responsible for reviewing and validating guidelines, risk reporting and risk management systems (Mohd Ariffin \& Kassim 2011). The internal control needs to be strengthened to improve the RMPs in IBIs.

2. The Effects Of Risk Management Practices On Islamic Banking Institutions Performance

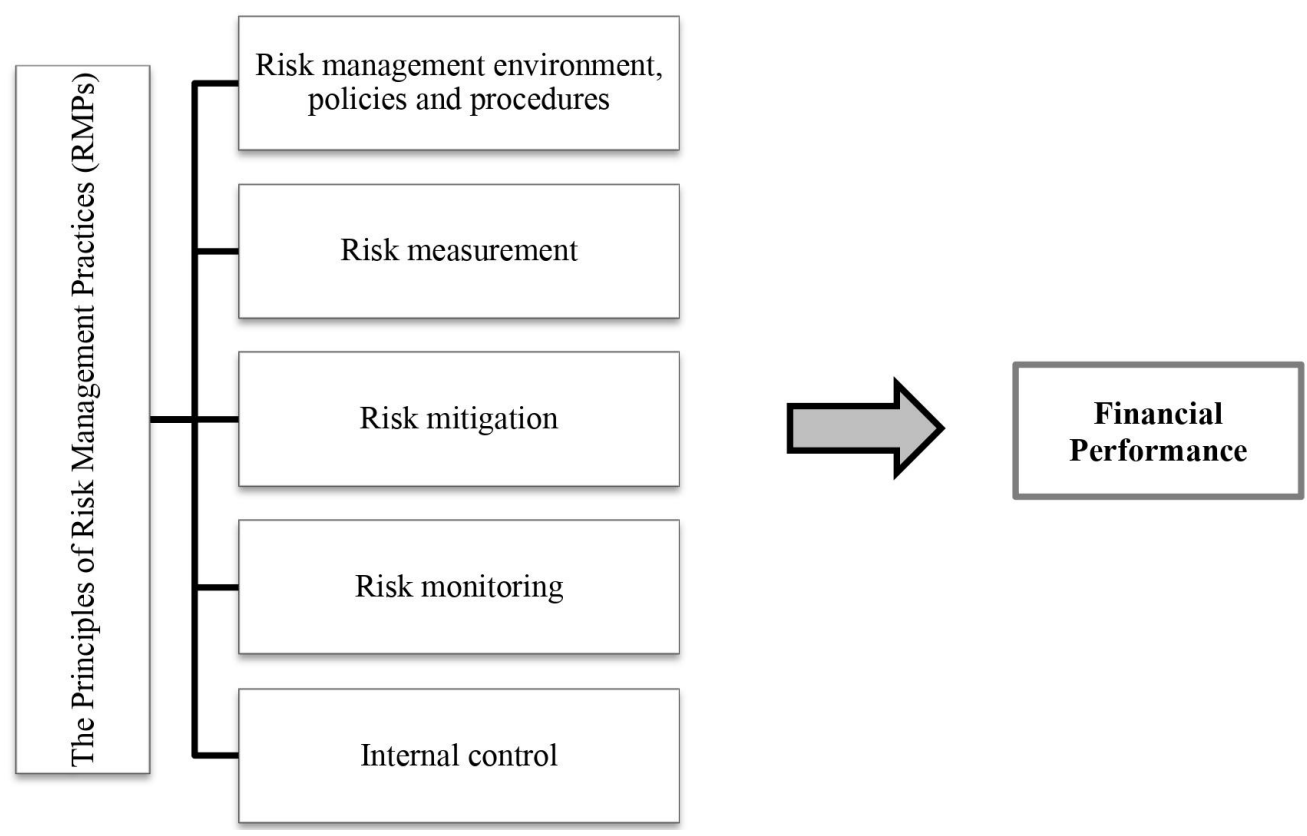

FIGURE 7. The Relationship between RMPs and Performance Source: Authors' Own (2020)

In order to achieve the next objective in analyzing the effects of the risk management practices on Islamic banking institutions performance (refer Figure 7), five (5) principles of RMPs has been briefly discussed by the authors and then link them with the financial performance. The details findings of the objective being developed are listed in the Table 4. Financial performance is referred to bank profitability that measured by return on assets (ROA) and return on equity (ROE). According to Mohd Ariffin and Kassim (2014) concluded that RMPs are positively associated with bank profitability. Moreover, Nazir et al. (2012) argued that effective and sound risk monitoring practices may lead to the highest performance of banks.

\subsection{Improvement In Return On Assets (ROA)}

Return on assets is the most widely used to measure bank's performance. ROA expressed as net income over average total assets. Mohd Ariffin and Kassim (2011) found in their study that there is a strong positive relationship between ROA and risk measurement, while Rauf and Irzath (2016) found a fair positive relationship between both of this. However, Zubairi and Ahson (2015) reported that risk measurement has a negative and significant relationship with ROA. Furthermore, study of Rauf and Irzath (2016) found that risk monitoring has very strong positive relationship with ROA, whereas a moderate 
positive relationship between both of this (Mohd Ariffin \& Kassim 2011). Apart from that, Rauf and Irzath (2016) stated that there is no significant relationship between risk mitigation practices and ROA. However, study by Mohd Ariffin and Kassim (2011) showed that risk mitigation practices have a significant correlation with ROA. This result support by Zubairi and Ahson (2015) found that risk mitigation has a negative and statistically significant relationship with return on assets. In addition, there are negative and significant relationship between ROA and risk management environment, policies and procedure as well internal control practices (Rauf \& Irzath 2016; Mohd Ariffin \& Kassim 2011). On the contrary, Zubairi and Ahson (2015) found that risk management environment, policies and procedures have a statistically insignificant and negative correlation with ROA. Overall, it can be concluded that good risk measurement and risk monitoring practices lead to the higher ROA for IBIs.
Thus, these findings indicate that IBIs should invest more resources for the development of IBIs related to process, measure and mitigate that adversely effect on profitability.

\subsection{Increase The Return On Equity (ROE)}

Return on equity reflects to the how well management of the bank used shareholders' investment. ROE can be expressed as net income over average stockholder equity. Mohd Ariffin and Kassim (2011) reported that risk management environment, policies and procedures as well as internal control practices have a positive relationship with ROE. Meanwhile, a negative correlation is found for risk measurement practices (Mohd Ariffin \& Kassim 2011). Based on this result, it can be conclude that good internal control practices and risk management environment, policies and procedures tend to have higher ROE for IBIs.

TABLE 4. The Effects of Risk Management Practices on Performance

\begin{tabular}{|c|c|c|c|c|c|c|c|c|c|c|}
\hline \multirow{3}{*}{ Authors } & \multirow{2}{*}{ Year } & \multirow{2}{*}{ 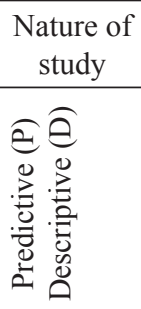 } & \multirow[t]{2}{*}{ Method } & \multirow[t]{2}{*}{ Country } & $\begin{array}{c}\text { Financial } \\
\text { Performance }\end{array}$ & \multicolumn{5}{|c|}{ Risk Management Practices } \\
\hline & & & & & 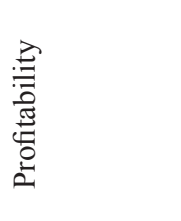 & 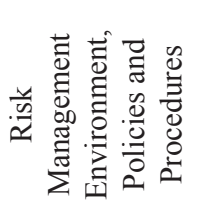 & 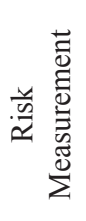 & 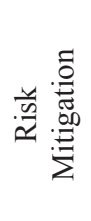 & 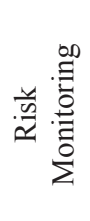 & 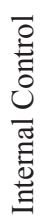 \\
\hline & & & & & ROA & & & & & \\
\hline $\begin{array}{c}\text { Mohd Ariffin, N. } \\
\text { \& Kassim, S. }\end{array}$ & 2011 & $\mathrm{P}$ & $\begin{array}{c}\text { Survey } \\
\text { Questionnaire }\end{array}$ & Malaysia & & $-*$ & + & $*$ & + & $-*$ \\
\hline $\begin{array}{l}\text { Rauf, A.L.A. \& } \\
\text { Irzath, K.L.M. }\end{array}$ & 2016 & $\mathrm{P}$ & $\begin{array}{c}\text { Multiple } \\
\text { Regression }\end{array}$ & Sri Lanka & & -* & + & / & + & $-*$ \\
\hline \multirow[t]{2}{*}{$\begin{array}{c}\text { Zubairi, J. \& } \\
\text { Ahson, S. }\end{array}$} & 2015 & $\mathrm{P}$ & $\begin{array}{c}\text { Survey } \\
\text { Questionnaire }\end{array}$ & Pakistan & & -1 & $-*$ & $-*$ & & \\
\hline & & & & & ROE & & & & & \\
\hline \multirow[t]{2}{*}{$\begin{array}{c}\text { Mohd Ariffin, N. } \\
\text { \& Kassim, S. }\end{array}$} & 2011 & $\mathrm{P}$ & $\begin{array}{c}\text { Survey } \\
\text { Questionnaire }\end{array}$ & Malaysia & & + & - & & & + \\
\hline & & Total & & & & 4 & 4 & 3 & 2 & 3 \\
\hline
\end{tabular}

Note + (positive) - (negative) * (significant) / (insignificant)

Source: Authors' Own (2020)

\section{Findings And Discussion}

This study systematically analyzed literature on the risk management practices and performance of Islamic banking institutions. Overall, this study finds that all principles of RMPs are having significant relationship with financial performance (ROA, ROE) of IBIs. Even though on average the IBIs have good RMPs, there is still a space for IBIs to improve their Shariah compliant risk mitigation tools or methods to ensure the soundness and effectiveness of managing risks for further development of new Islamic banking products.

Within the scope of this, the findings on RMPs show the importance of applied all the aspect risk management process to ensure the risk can be recognized at early stage. However, studies by the Rhanoui and Belkhoutout (2019) found that in practical, not all Islamic banks carried out the risk management process as reviewed from Islamic banks reports. They failed to report all risk they faced in daily operations, and they did not give in details about how all those risks being identified as well as little information regarding their management was provided in the bank reports. This indicates the IBIs lack of standardization in financial reporting (Rhanoui \& Belkhoutout 2019). Due to this matter, there is a need to develop a guideline or standard in reporting risk to ensure all Islamic banks reports in similar way in annual reports. 
Furthermore, the findings also showed that IBIs seem not use the more technically advance risk measurement techniques in practices (e.g., internal-based rating system, simulation techniques and risk adjusted rate of returnRAROC) except for value at risk and stress testing. Thus, it is clearly showed that Islamic banks lacks resources and appropriate quantitative measures because of not having an appropriate database that could facilitate the risk measurement method. This argument support by Mohd Ariffin and Kassim (2011) stated that Islamic banks are still new, and they do not have adequate resources and systems to adopt more technically advances risk measurement techniques. As a result, study of Rhanoui and Belkhoutout (2019) claimed that Islamic banks' report just mentions some measurement tools, but this is only suitable to apply to the risks that are typical with their conventional counterparts.

Moving to the risk mitigation practices, the results show that IBIs not fully used Shariah compliant risk mitigation methods that are differ from those used by conventional banks. As argued by Mohd Ariffin and Kassim (2014), the reason due to these methods still gets some objections by the fiqh scholars, for example bay'salam, which according to them, it can lead to the speculation (Usmani 1996).

In addition, IBIs are found to have good risk monitoring practices in term of human capital (for example Shariah and risk management committee) but they seem insufficient in term of risk monitoring system or in other words do not have risk coding-system that simplified the analysis of relevant risks. To a large extent, Rhanoui and Belkhoutout (2019) stated that codingsystem suggests that each risk of Islamic bank is coded for additional reference to that risk. Consequently, this would significantly assist risk monitoring and risk reporting in IBIs.

On another note, to ensure the effectiveness of RMPs, IBIs must ensure that their staffs have good understanding on the risks that are inherent in their banking operation. Not only that, full in-depth understanding of risk management also compulsory particularly in the financial intermediation activities (Rosman 2009). Based on the past literature, it revealed that comprehensive understanding risk and risk management is crucial aspect influencing the effectiveness of RMPs (Rosman 2009). Furthermore, this aspect will be able to increase awareness regarding the importance of risk management as well as may protect Islamic banks from bad risk factors (Mohamed 2018). In this case, employee involvement and knowledge creation are the best ways to change the attitude and mindset of the employee in order to bring them having a better understanding that managing risk is important for success. Hence, employee involvement and knowledge creation can be done through the followings:-

\section{Training programs}

Khattak et al (2013) suggest that IBIs policy could motivate training programs in the field of risk management and
Islamic ethics. Furthermore, quality related training is needed for improving the performance of financing in Islamic banking system and to avoid obstacles that bank faced (Ahmed 2008). More precisely, IBIs should provide training to their risk management staff so that they can have sufficient skills on the Islamic mode of financing as well as a complete understanding about this subject matter. On another note, training should be considered as an investment in human capital, which is important in contributing to the success of an institution.

\section{Empowerment}

Instills an individual independence is crucial to retain knowledge. In this case, self-independency requires physical and mental empowerment to make sure the employee share and apply their knowledge various circumstances. Moreover, Higher Education Commission (HEC) should act to introduce the courses for risk management in Islamic banking at higher educational institutes so that business graduates would have better understanding and know how to manage and conduct potential risk in IBIs.

\section{Team orientation}

Knowledge is usually can be create by a group of people rather than by self-employed individuals. Therefore, Memon et al. (2017) indicates that institutions that have a team-oriented culture usually doing better than those have individual-oriented culture particularly when the job task performed require an experience, knowledge, skills and judgement.

\section{CONCLUSION}

This study aims to systematically review the existing literature on the risk management practices and performance of Islamic banking institutions. It reflects a basic understanding of how IBIs respond toward the risk incur in their banking operation based on adapted PRISMA Statement by using eight (8) electronic journal databases; Web of Science, Science Direct, Scopus, Emerald Insight, Sage, Wiley Online Library, Dimensions and Google Scholar. With respect to the systematic review process and efforts by the authors, a total of 16 themes and 17 sub-themes have been categorized regarding the RMPs in IBIs. This study has identified five (5) principles of RMPs namely risk management environment, policies and procedures, risk monitoring, risk measurement, risk mitigation and internal control. The findings of the study concluded that IBIs have good risk mitigation practices followed by risk management environment, policies and procedures and risk monitoring practices as compared to risk measurement practices and internal control which led to significant effect on financial performance (ROA, ROE) of IBIs. This indicates that change in the practices of risk management and principles will have certain effect on IBIs performance. 
Based on the findings drawn from the primary studies, risk management is very important as it helps banking institutions reduce the chances and effects of adverse events while enhancing the realization of opportunities i.e., minimize risk and maximize returns. Comprehensive risk management requires allocation of resources to finance tangible and intangible costs, such as hiring dedicated risk management personnel, putting procedures in place and investing in systems. Overall, risk management should have positive effects on IBIs' ability to achieve their strategic objectives, improve operations, ultimately leading to value creation.

In addition, the regulatory authorities and policy makers need to review the rules and guidelines as well as emphasize strong governance policy so that Islamic banking industry can act and perform well and contribute to the country's economy. As a policy implication, this study would help the policy makers, regulators, central banks and top management of Islamic banking sector to relook on these key areas of banks to tighten their policies and take remedial action if they feel weaknesses in the practices of risk management. In a nutshell, the current study shows that human capital and bank's behavior are the most crucial factors to ensure risk can be manage properly despite of having a good RMPs or in other words enhancing the performance of IBIs in the economic development.

There are several recommendations led by the systematic review process and findings of this study as a reference for future researchers. Much is unknown about the RMPs and its relationship with performance of the Islamic banking. Therefore, several areas of study need to be given more attention for improvement in future studies. First, most of the articles in the review are fully quantitative (29), while (15) are fully qualitative in nature and also the authors not empirically test the effects (RMPs-Performance). Hence, future research should consider using mixed methods and more qualitative design which can result in increased transparency and the ability to critically evaluate the rigorous review methods to research synthesis. Afterwards, this study uses only eight databases, future studies should consider uses more than eight of it (e.g., Taylor Francis, Springer, Oxford Journals), the probability to get more relevant article is high. Moreover, this study examines the RMPs and performance only concentrated on IBIs, for future studies, it is possible to obtain empirical data about RMPs in IBIs and CBIs from the countries that is not conducted yet and compare result with the result of this study.

\section{ACKNOWLEDGEMENT}

This research was funded by UKM Research University Funds, UKM-DIPM-061-2011 \& UKM-GUP-EP-07-16-121. The authors would also like express gratitude for the financial assistance from the Faculty of Economics and Management, Universiti Kebangsaan Malaysia (UKM), EP-2018-001.

\section{REFERENCES}

Abdul Rahman, R., Alsmady, A., Ibrahim, Z. \& Muhammad, A.D. 2014. Risk Management Practices in Islamic Banking Institutions: A Comparative Study between Malaysia and Jordan. Journal of Applied Business Research 30(5): 1295-1304.

Abdul Rahman, R., Ibrahim, Z., Tohirin, A., Muhammad, A.D. \& Suryaputri, R.V. 2016. Risk Management Practices in Islamic Banking Institutions: A Comparative Study between Malaysia and Indonesia. International Journal of Sciences and Research 72(12): 207-220.

Abdullah, M., Shahimi, S. \& Ismail, A.G. 2011. Operational risk in Islamic banks: examination of issues. Qualitative Research in Financial Markets 3(2): 131-151.

Ahmad, E., Khan, D., Akbar, N., Shoaib, M. \& Ullah, K. 2013. Pakistan's Islamic Banks Risk Management Practices. European Journal of Banking and Finance 10: 2668-3458.

Ahmed, G.A. 2008. The implication of using profit and loss sharing modes of finance in the banking system, with a particular reference to equity participation (partnership) method in Sudan. Humanomics 24(3): 182-206.

Akhtar, S. \& Jahromi, M. 2015. Impact of the global financial crisis on Islamic and conventional stocks and bonds. Accounting and Finance, 1-33.

Akkizidis, I. \& Khandelwal, S.K. 2008. Financial Risk Management for Islamic Banking and Finance. Palgrave Macmillan, First Ed.

Al-Hares, O.M. \& Saleem, K. 2017. Islamic Banks Financial Performance and Implications of basel III Standards in the GCC: An Empirical Analysis. Review of Economics \& Finance 7(1): 80-97.

AlKhouri, R. \& Arouri, H. 2019. The effect of diversification on risk and return in banking sector: Evidence from the Gulf Cooperation Council countries. International Journal of Managerial Finance 15(1): 100-128.

Al Rahahleh, N., Bhatti, M.I. \& Misman, F.N. 2019. Developments in Risk Management in Islamic Finance. Journal of Risk and Financial Management 12(37): 1-22.

Al-Tamimi, H.A.H. \& Al-Mazrooei, F.M. (2007). Banks' risk management: a comparison study of UAE national and foreign banks. The Journal of Risk Finance 8(4): 394-409.

Archer, S., Abdel Karim, R.A. \& Sundararajan, V. 2010. Supervisory, regulatory, and capital adequacy implications of profit-sharing investment accounts in Islamic finance. Journal of Islamic Accounting and Business Research 1(1): 10-31.

Baltensperger, E. 1980. Alternative approaches to the theory of the banking firm. Journal of Monetary Economics 6: 1-37.

Bank for International Settlements, Financial Stability Board. 2009. Risk Management Lessons from the Global Banking Crisis of 2008. Basel: Bank for International Settlements.

Bank Negara Malaysia. 2001. Best Practices for the Management of Credit Risk.

Bank Negara Malaysia. 2001. Concept Paper-Guide Lines Risk Governance.

Bank Negara Malaysia. 2012. Guidelines on Risk Management and Internal Controls for Conduct of Money Services Business (MSB).

Bank Negara Malaysia. 2013. Risk Governance.

Basel Committee on Banking Supervision. 2001. Operational Risk, consultative document. Basel: Bank for International Settlements. 
Basel Committee on Banking Supervision. 2011. Principles for the Sound Management of Operational Risk. Basel: Bank for International Settlements.

Basel Committee on Banking Supervision. 2019. Supervisory Review Process. Basel: Bank for International Settlements.

Casu, B., Girardone, C. \& Molyneux, P. 2006. Introduction to Banking. Harlow: FT Prentice Hall, Pearson Education Ltd.

Cecchetti, S.G. 2008. Money, Banking and Financial markets (2nd Ed.). New York: McGraw-Hill Irwin.

Chazi, A. \& Syed, L.A.M. 2010. Risk exposure during the global financial crisis: the case of Islamic banks. International Journal of Islamic and Middle Eastern Finance and Management 3(4): 321-333.

Crane, L.M. \& Leatham, D.J. 1993. Profit and Loss Sharing in Agriculture: An Application of Islamic Banking. Agribusiness 9(4): 403-412.

Daher, H., Masih, M. \& Ibrahim, M. 2015. The unique risk exposures of Islamic banks' capital buffers: A dynamic panel data analysis. Journal of International Financial Markets, Institutions and Money 36: 1-41.

Diamond, D.W. \& Dybvig, P.H. 1983. Bank runs, deposit insurance, and liquidity. Journal of Political Economy 91(3): 401-419.

Diamond, D.W. \& Rajan, R.G. 2001. Banks, short-term debt and financial crises: Theory, policy implications and applications. Carnegie-Rochester Conference Series on Public Policy 54(1): 37-71.

Diaw, A. \& Mbow, A. 2011. A comparative study of the returns on Mudarabah deposit and on equity in Islamic banks. Humanomics 27(4): 229-242.

Dimov, S. \& Smirnov, V. 2020. Risk Management in Dual Banking Systems: Islamic Ethical and Conventional Banking. Review of Business and Economics Studies 7(4): 6-12.

Djojosugito, R. 2008. Mitigating legal risk in Islamic banking operations. Humanomics 24(2): 110-121.

Dolgun, M.H., Ng, A. \& Mirakhor, A. 2020. Need for calibration: applying a maximum threshold to liquidity ratio for Islamic banks. International Journal of Islamic and Middle Eastern Finance and Management 13(1): 56-74.

Elsevier. 2019. Scopus. Retrieved 24 December 2019 from https://www.elsevier.com/solutions/scopus.

Fakhrunnas, F. \& Imron, M.A. 2019. Assessing Financial Risk and Regional Macroeconomic Influence to Islamic Rural Bank Performance. Global Review of Islamic Economics and Business 7(1): 049-055.

Farooq, M. \& Zaheer, S. 2015. Are Islamic Banks More Resilient During Financial Panics? Pacific Economic Review 20(1): 101-124.

Flemming, K., Booth, A., Hannes, K., Cargo, M. \& Noyes, J. 2018. Cochrane Qualitative and Implementation Methods Group guidance series-paper 6: reporting guidelines for qualitative, implementation, and process evaluation evidence syntheses. Journal of Clinical Epidemiology 97: 79-85.

Fry, M.J. 1988. Money, Interest, and Banking in Economic Development. Baltimore, Md.: Johns Hopkins University Press.

Ghassan, H.B. \& Guendouz, A.A. 2019. Panel modeling of z-score: evidence from Islamic and conventional Saudi banks. International Journal of Islamic and Middle Eastern Finance and Management 12(3): 448-468.
Gusenbauer, M. \& Haddaway, N.R. 2019. Which academic search systems are suitable for systematic reviews or metaanalyses? Evaluating retrieval qualities of Google Scholar, PubMed, and 26 other resources. Res Syn Meth, 1-37.

Haddaway, N. R., Collins, A. M., Coughlin, D. \& Kirk, S. 2015. The Role of Google Scholar in Evidence Reviews and Its Applicability to Grey Literature Searching. Plos One 10(9): e0138237.

Halevi, G., Moed, H. \& Bar-Ilan, J. 2017. Suitability of Google Scholar as a source of scientific information and as a source of data for scientific evalutaion-Review of the Literature. Journal of Informetrics 11: 823-834.

Hassan, A. 2009. Risk management practices of Islamic banks of Brunei Darussalam. The Journal of Risk Finance 10(1): 23-37.

Higgins, J.P.T., Altman, D.G., Gøtzsche, P.C., Jüni, P., Moher, D. \& Oxman, A.D. et al. 2011. The Cochrane Collaboration's tool for assessing risk of bias in randomised trials. BMJ (Online) 343 (7829): 1-9.

Holland, J. 2010. Banks, knowledge and crisis: a case of knowledge and learning failure. Journal of Financial Regulation and Compliance 18(2): 87-105.

Hook, D.W., Porter, S.J. \& Herzog, C. 2018. Dimensions: Building Context for Search and Evaluation. Frontiers in Research Metrics and Analytics 3(23).

Hoseth, A. 2011. Google Scholar. Advisor Reviews: 36-39.

How, J.C.Y., Abdul Karim, M. \& Verhoeven, P. 2005. Islamic Financing and Bank Risks: The Case of Malaysia. Thunderbird International Business Review 47(1): 75-94.

Hussain, H.A. \& Al-Ajmi, J. 2012. Risk management practices of conventional and Islamic banks in Bahrain. The Journal of Risk Finance 13(3): 215-239.

IMF. 2008. Global Financial Stability Report: Containing Systemic Risks and Restoring Financial Soundness. IMF Multimedia Services Division, Washington: DC.

Iqbal, Z. \& Mirakhor, A. 2007. An Introduction to Islamic Finance: Theory and Practice. John Wiley \& Son (Asia) Pte Ltd: Singapore.

Islamic Financial Services Board. 2005. Guiding principles of risk management for institutions (other than insurance institutions) offering only Islamic financial services. Published Standard No. 1. Kuala Lumpur: IFSB.

Ismail, A.G. \& Ahmad, I. 2006. Does the Islamic financial system design matter? Humanomics 22(1): 5-16.

Ismal, R. 2010. Volatility of the returns and expected losses of Islamic bank financing. International Journal of Islamic and Middle Eastern Finance and Management 3(3): 267-279.

Jahwari, N.A. \& Khan, M.F. 2016. Organizational Learning Mechanisms in Sohar University. Humanities \& Social Sciences Reviews 4(2): 76-87.

Kadhim, L.J., Al-Sahrawardee, H.M.S.M. \& Karoom, C.B.M. 2019. The role of stress testing scenarios in reducing the banks-risks: An applied study. Polish Journal of Management Studies 20(2): 279-289.

Kamil, K.H., Abdullah, M., Shahimi, S. \& Ismail, A.G. 2010 The subprime mortgages crisis and Islamic securitization. International Journal of Islamic and Middle Eastern Finance and Management 3(4): 386-401.

Kashyap, A., Rajan, R. \& Stein, J. 2002.Banks as liquidity providers: An explanation for the coexistence of lending and deposit-taking. Journal of Finance 57: 33-73.

Keynes, J.M. 1936. The General Theory of Employment. Interest and Money. London: Macmillan. 
Khalid, S. \& Amjad, S. 2012. Risk management practices in Islamic banks of Pakistan. The Journal of Risk Finance 13(2): 148-159.

Khan, M.M. \& Bhatti, M.I. 2008. Development in Islamic banking: a financial risk-allocation approach. The Journal of Risk Finance 9(1): 40-51.

Khan, T. \& Ahmed, H. 2001. Risk Management: An Analysis of Issues in Islamic Financial Industry. Occasional Paper No. 5, Islamic Development Bank, Islamic Research and Training Institute, Jeddah.

Khattak, N.A., Khashif-Ur-Rehman, Ullah, W. \& Ullah, M. 2013. Risk management practices and attitude of Pakistani Islamic banking system employees. African Journal of Business Management 7(33): 3202-3211.

Kitchenham, B. \& Charters, S. 2007. Guidelines for performing systematic literature reviews in software engineering.

KPMG International. 2009. Never Again? Risk Management in Banking Beyond the Credit Crisis. Berne: KPMG International

KPMG. 2020. Global Banking Fraud Survey. Retrieved from https://assets.kpmg/content/dam/kpmg/xx/pdf/2019/05/ global-banking-fraud-survey.pdf (accessed on 9 September 2021).

L'Huillier, B., Rizwan, M.S. \& Ashraf, D. 2018. Net Stable Funding Requirement under Basel III: Loan Portfolio Growth Matters. Asia-Pacific Journal of Financial Studies 47: 477-500.

Liberati, A., Altman, D.G., Tetzlaff, J., Mulrow, C., Gøtzsche, P.C., Ioannidis, J.P.A. \& . . Moher, D. 2009. The PRISMA statement for reporting systematic reviews and metaanalyses of studies that evaluate health care interventions: explanation and elaboration. Italian Journal of Public Health 6(4): 354-391.

Magalhaes, R. \& Al-Saad, S. 2013. Corporate governance in Islamic financial institutions: the issues surrounding unrestricted investment account holders. Corporate Governance 13(1): 39-57.

Mairafi, S.L., Hassan, S. \& Mohamed Arshad, S.B. 2018. An Analysis of The Literature on Islamic Bank Risk-Taking. Academy of Accounting and Financial Studies Journal 22(special issue): 1-7.

Makiyan, S.N. 2008. Risk Management and Challenges in Islamic Banks. Journal of Islamic Economics, Banking and Finance 4(3): 45-54.

Masood, O. \& Fry, J. 2012. Risk management and BaselAccord-implementation in Pakistan. Journal of Financial Regulation and Compliance 20(3): 293-306.

Memon, S.B., Syed, S. \& Arain, G.A. 2017. Employee Involvement and the Knowledge Creation Process: An Empirical Study of Pakistani Banks. Global Business and Organizational Excellence, 53-63.

Mishkin, F.S. 1997. The causes and propagation of financial instability: lessons for policymakers. In: Hakkio, C. (Ed.), Maintaining Financial Stability in a Global Economy. Federal Reserve Bank of Kansas City, Kansas City, pp. 55-96.

Mohamed Ariff. 2014. Whither Islamic Banking? The World Economy, 733-746.

Mohamed Shaffril, H.A., Krauss, S.E. \& Samsuddin, S.F. 2018. A systematic review on Asian's farmers' adaptation practices towards climate change. Science of the Total Environment 644: 683-695.
Mohamed, W.M.H. 2018. Difference between Conventional Banks and Islamic Banks in the Middle East Region: A Risk Management Approach. JRL of the Faculty of Commerce for Scientific Research 55(1): 1-27.

Mohammad, S. 2013. Liquidity Risk Management in Islamic Banks: A Survey. Afro Eurasian Studies 1(2): 215-230.

Mohd Ariffin, N. \& Kassim, S. 2011. Risk management practices and financial performance of Islamic banks. Paper presented at the Malaysian Evidence Paper presented at the 8th International Conference on Islamic Economics and Finance. National Convention Center, Qatar. 1-23.

Mohd Ariffin, N. \& Kassim, S. 2014. Risk Management Practices of Selected Islamic Banks in Malaysia. Aceh International Journal of Social Sciences 3(1): 26-36.

Mohd Yusof, R., Bahlous, M. \& Haniffa, R. 2016. Rental rate as an alternative pricing for Islamic home financing an empirical investigation on the UK Market. International Journal of Housing Markets and Analysis 9(4): 601-626.

Mohd Yusof, R., Kassim, S., Majid, M.S.A. \& Hamid, Z. 2011. Determining the viability of rental price to benchmark Islamic home financing products: Evidence from Malaysia. Benchmarking: An International Journal 18(1): 69-85.

Moher, D., Liberati, A., Tetzlaff, J., Altman, D.G. \& The PRISMA Group. 2009. Preferred reporting items for systematic reviews and Meta Analyses: the PRISMA statement. PLoS Med 6(7).

Mokni, R.B.S., Echchabi, A., Azouzi, D. \& Rachdi, H. 2014. Risk management tools practiced in Islamic banks: evidence in MENA region. Journal of Islamic Accounting and Business Research 5(1): 77-97.

Muhammad, A.D. 2016. Risk Management Practices in Islamic Banking Institutions: A Comparative Study between Nigeria and Malaysia. Working Papers 2016-14, The Islamic Research and Teaching Institute (IRTI).

Muneeza, A., Nik Yusuf, N.N.A. \& Hassan, R. 2011. The possibility of application of salam in Malaysian Islamic banking system. Humanomics 27(2): 138-147.

Nazir, M.S., Daniel, A. \& Nawaz, M.M. 2012. Risk Management Practices: A Comparison of Conventional and Islamic Banks in Pakistan. American Journal of Scientific Research 68: $114-122$.

Ng, S.L., Chin, W.C. \& Chong, L.L. 2017. Multivariate market risk evaluation between Malaysian Islamic stock index and sectoral indices. Borsa Istanbul Review 17(1): 49-61.

Okoli, C. 2015. A Guide to Conducting a Standalone Systematic Literature Review. Communications of the Association for Information Systems 37: 879-910.

Patino, C. M. \& Ferreira, J.C. 2018. Inclusion and exclusion criteria in research studies: definitions and why they matter. J Bras Pneumol 44(2): 84-84.

Peacock, R., Martin, P., Burrow, M., Petty, J., Kenwn, A., Scott, D. \& Martin, J. 2003. Financial Management. 3rd Edition. Australia: Prentice Hall.

Pellegrina, L.D. 2012. Does capitalization enhance efficient risk undertaking? A comparison between Islamic and conventional banks. Accounting Research Journal 25(3): 185-207.

Petticrew, M. \& Roberts, H. 2006. Systematic reviews in the social sciences. Malden, MA: Blackwell Publishing.

Rauf, A.L.A. \& Irzath, K.L.M. 2016. Effect of Risk Management Practices on the Performance of Islamic Banks and Islamic Window in Sri Lanka. International Journal of Advances in Management, Economics and Entrepreneurship 3(6): $1-7$. 
Rhanoui, S. \& Belkhoutout, K. 2019. Risks Faced by Islamic Banks: A Study on the Compliance between Theory and Practice. International Journal of Financial Research 10(2): 137-146.

Riordan, M.H. 1993. Chapter 11: Competition and bank performance: a theoretical perspective. In Mayer, C. \& Vives, X. (Eds.), Capital markets and financial intermediation (pp. 328-343). Cambridge: Cambridge University Press.

Rosly, S.A. \& Mohd. Zaini, M.A. 2008. Risk-return analysis of Islamic banks' investment deposits and shareholders' fund. Managerial Finance 34(10): 695-707.

Rosman, R. \& Abdul Rahman, A.R. 2013. Risk management practices of Islamic banks: International evidence. Islamic Banking and Financial Crisis: Reputation, Stability and Risks, 106-123.

Rosman, R. \& Abdul Rahman, A.R. 2015. The practice of IFSB guiding principles of risk management by Islamic banks: International evidence. Journal of Islamic Accounting and Business Research 6(2): 150-172.

Rosman, R. 2009. Risk Management Practices and Risk Management Processes of Islamic Banks: A Proposed Framework. International Review of Business Research Papers 5(1): 242-254.

Sabato, G. 2009. Financial crisis: where did risk management fail? Available at SSRN: http://ssrn.com/abstract $1 / 141460762$.

Sealey, C. \& Lindley, J.T. 1977. Inputs, outputs and a theory of production and cost at depositary financial institutions. Journal of Finance 32: 1251-1266.

Siddiqui, A. 2008. Financial contracts, risk and performance of Islamic banking. Managerial Finance 34(10): 680-694.

Sierra-Correa, P.C. \& Cantera Kintz, J.R. 2015. Ecosystembased adaptation for improving coastal planning for sealevel rise: a systematic review for mangrove coasts. Mar. Policy 5: 385-393.

State Bank of Pakistan. 2007. Draft risk management guidelines for Islamic banking institutions. Available from the State Bank of Pakistan webpage: www.sbp.org.pk/ibd/2007/ Draft-Risk-Management-Guidelines.pdf.

Sundarajan, V. \& Errico, L. 2002. Islamic Financial Institutions and Products in the Global Financial System: Key Issues in Risk Management and Challenge Ahead. IMF Working Paper, International Monetary Fund.

Sutrisno \& Agus Widarjono. 2018. Maqasid sharia index, banking risk and performance cases in Indonesian Islamic banks. Asian Economic and Financial Review 8(9): $1175-1184$
Tobin, J. 1963. Commercial banks as creators of money, Cowles Foundation Paper 205 reprinted. In D. Carson (Ed.), Banking and Monetary Studies. Irwin: Homewood.

Tobin, J. 1969. A general equilibrium approach to monetary theory. Journal of Money, Credit and Banking 1: 15-29.

Uddin, M.A. 2015. Risk Management Practices in Islamic Bank: A Case Study of Islamic Bank Bangladesh Limited. MPRA Paper, 1-39.

Web of Science Group. 2019. Web of Science: Confident research begins here. Retrieved 24 December 2019 from https://clarivate.com/webofsciencegroup/ solutions/webof-science/.

Werner, R.A. 2005. New Paradigm in Macroeconomics. Basingstoke: Palgrave Macmillan.

Whittemore, R. \& Knafl, K. 2005. The integrative review: updated methodology. Methodological issues in nursing research 52(5): 546-553.

Zakaria, R.H. \& Ismail, A.G. 2008. Does Islamic banks' securitization involvement restrain their financing activity? Humanomics 24(2): 95-109.

Zubairi, J. \& Ahson, S. 2015. Balancing Risk Management and Profitability. Pakistan Business Review, 264-287.

Siti Najihah Noory

Faculty of Economics and Management

Universiti Kebangsaan Malaysia

43600 UKM Bangi, Selangor

Email: najihahnoory@gmail.com

Shahida Shahimi*

Faculty of Economics and Management

Universiti Kebangsaan Malaysia

43600 UKM Bangi, Selangor

Email: shahida@ukm.edu.my

Abdul Ghafar Ismail

Faculty of Economics and Muamalat

Universiti Sains Islam Malaysia

Bandar Baru Nilai

71800 Nilai, Negeri Sembilan

Email: agibab62@gmail.com

*Corresponding author 